\title{
Towards a General Theory of Deep Downturns
}

\section{Joseph E. Stiglitz ${ }^{1}$}

The world has been plagued by episodic deep downturns. The crisis that began in 2008 in the United States was the most recent, the deepest and longest in three quarters of a century. It came in spite of alleged "better" knowledge of how our economic system works, and belief among many that we had put economic fluctuations behind us. Our economic leaders touted the achievement of the Great Moderation. ${ }^{2}$ As it turned out, belief in those models actually contributed to the crisis. It was the assumption that markets were efficient and self-regulating and that economic actors had the ability and incentives to manage their own risks that had led to the belief that self-regulation was all that was required to ensure that the financial system worked well, and that there was no need to worry about a bubble. The idea that the economy could, through diversification, effectively eliminate risk contributed to complacency-even after it was evident that there had been a bubble. Indeed, even after the bubble broke, Bernanke could boast that the risks were contained. ${ }^{3}$ These beliefs were supported by (pre-crisis) DSGE models-models which may have done well in more normal times, but had little to say about crises. Of course, almost any "decent" model would do reasonably well in normal times. And it mattered little if, in normal times, one model did a slightly better job in predicting next quarter's growth. What matters is predicting-and preventing-crises, episodes in which there is an enormous loss in well-being. These models did not see the crisis coming, and they had given confidence to our policy makers that, so long as inflation was contained-and monetary authorities boasted that they had done this - the economy would perform well. At best, they can be thought of as (borrowing the term from Guzman (2014) "models of the Great Moderation," predicting "well" so long as nothing unusual happens. More generally, the DSGE models have done a poor job explaining the actual frequency of crises. $^{4}$

\footnotetext{
${ }^{1}$ Presidential Address to the $17^{\text {th }}$ World Congress of the International Economic Congress, Dead Sea, Jordan June, 2014. This address is based in part on joint work with Bruce Greenwald and Martin Guzman. Helpful discussions with Adair Turner, particularly on Part III, and with Rob Johnson, Martin Guzman, and Arjun Jayadev, are gratefully acknowledged. I am indebted to INET for financial support, and to Feiran Zhang, Debarati Ghosh and Ruoke Yang for research assistance. The first two parts of this lecture are a development of ideas presented earlier in Stiglitz $(2011,2013)$. For a more extensive list of references, see those papers.

${ }^{2}$ McConnell and Perez-Quiros (2000) were among the first ones to identify the Great Moderation, which they attributed to changes in inventory management. Indeed, in his presidential address to the AEA, Lucas (2003) went on to describe how the central problem of depression-prevention has been largely resolved. His conclusion was obviously wrong. So too, I suspect were those attributing the Great Moderation to better management by the Central Bank (or even to better inventory management). Inflation was tamed in part by the increasing supply of consumer goods at low prices coming from China. With the decline in the manufacturing sector, inventories had simply become less important. Finally, there was an element of good luck: there was nothing comparable to the oil price shocks of the 70s with which Central Banks had to contend.

${ }^{3}$ On March $28^{\text {th }} 2007$ in testimony before the US Congress, after the bubble had already broken, the Fed Chairman asserted: "the impact on the broader economy and financial markets of the problems in the subprime market seems likely to be contained."

${ }^{4}$ See Guzman (2013), who explains the flaws in the results of Aguiar and Gopinath (2006) who had a more optimistic view of the ability of such models to explain the frequency of crises.
} 
Of course, deep downturns have marked capitalist economies since the beginning. It took enormous hubris to believe that the economic forces which had given rise to crises in the past were either not present, or had been tamed, through sound monetary and fiscal policy. ${ }^{5}$ It took even greater hubris given that in many countries conservatives had succeeded in dismantling the regulatory regimes and automatic stabilizers that had helped prevent crises since the Great Depression. It is noteworthy that my teacher, Charles Kindleberger, in his great study of the booms and panics that afflicted market economies over the past several hundred years had noted similar hubris exhibited in earlier crises. (Kindleberger, 1978)

Those who attempted to defend the failed economic models and the policies which were derived from them suggested that no model could (or should) predict well a "once in a hundred year flood." But it was not just a hundred year flood-crises have become common. It was not just something that had happened to the economy. The crisis was man-made-created by the economic system. Clearly, something is wrong with the models.

Studying crises is important, not just to prevent these calamities and to understand how to respond to them-though I do believe that the same inadequate models that failed to predict the crisis also failed in providing adequate responses. (Although those in the US Administration boast about having prevented another Great Depression, I believe the downturn was certainly far longer, and probably far deeper, than it need to have been.) I also believe understanding the dynamics of crises can provide us insight into the behavior of our economic system in less extreme times.

This lecture consists of three parts. In the first, I will outline the three basic questions posed by deep downturns. In the second, I will sketch the three alternative approaches that have competed with each other over the past three decades, suggesting that one is a far better basis for future research than the other two. The final section will center on one aspect of that third approach that I believe is crucialcredit. I focus on the capitalist economy as a credit economy, and how viewing it in this way changes our understanding of the financial system and monetary policy.

\section{Three fundamental questions}

Economic systems have always exhibited volatility, and economic theorists have long sought to describe and explain these fluctuations. In the United States, the National Bureau of Economic Research began as an attempt to characterize and date business cycles (for instance, with the work of Wesley Mitchell and his student, Simon Kuznets). In the middle of the twentieth century, a number of theories explaining why markets endogenously give rise to cyclical fluctuations were developed. Particular

\footnotetext{
${ }^{5}$ This kind of hubris was not only exhibited by policymakers, but also by academics. Robert Lucas, in his presidential address to the American Economic Association, famously said:, "[The] central problem of depression prevention has been solved, for all practical purposes, and has in fact been solved for many decades." (Lucas, 2003)
} 
attention was paid to inventory cycles. But much of this literature was concerned with small oscillations, not the deep downturns that are the focus of this lecture.

\section{A. What is the source of large perturbations?}

The key questions are: Is the source of those major perturbations exogenous or endogenous? And how do economic structures and policies affect the depth and duration of these perturbations?

The standard models (referred to earlier in the introduction, and discussed at greater length below) assume that the source of the disturbances to the economy is exogenous. To me, it is clear that that is simply wrong: the credit and housing bubble that were at the center of the 2008 crisis was created by the market. The bubble was a market phenomenon. To assume that it was exogenous is to assume that there is nothing that we can do either to prevent the creation of a bubble or to curtail its size.

Equally troublesome, much of the literature referred to below assumes that the shocks to the economic system are technology shocks. As I explain below, when we look at many of the key economic fluctuations, it is hard to see any changes to technology that could have generated such changes.

By the same token, one of the reasons that the crisis spread so quickly and virulently beyond the borders of the United States was globalization ${ }^{6}$-the result of policies that had been pursued over the previous quarter of a century that resulted, for instance, in much greater financial integration. Again, it is simply wrong to assume that the shocks confronting a country are exogenous: even if the origin of shocks were exogenous, the extent to which a country is exposed to shocks is endogenous. (Indeed, in the case of developing countries, there is a wealth of evidence that most of the shocks to their economies come from outside their borders. $)^{7}$

\section{B. How can we explain magnitude of volatility?}

The change in the physical state variables is typically small, and yet, in deep downturns, the change in output and employment are typically large. Consider the 2008 crisis. There was no destruction of physical or human capital, as often happens in war or in a natural disaster. Yet there were huge changes in the level of macro-economic activity, corresponding to large changes in the behavior of households and firms.

In many cases, shocks seem to have been amplified, rather than "buffered," as suggested by traditional economic models, where price adjustments and inventories help absorb shocks and dampen the size of fluctuations.

Earlier literature (the Samuelson accelerator-multiplier model) tried to explain amplification through an investment accelerator: an increase in (expected) growth leads to an increase in the demand for investment goods (to produce the larger output), which then amplifies growth itself. But in the aftermath of the rational expectations revolution, it appeared hard to reconcile such behavior and the

\footnotetext{
${ }^{6}$ Mendoza and Quadrini (2009).

${ }^{7}$ For instance, Popov and Udell (2010).
} 
cycles to which the accelerator-multiplier model gave rise with rational expectations. For instance, in one variant of these models, at some point the economy reached full employment. This constrained growth. But prior to that constraint binding, investors should have realized that this would occur; and this would have constrained investment in these earlier periods.

But Greenwald and Stiglitz, in a series of papers beginning in the $1980 \mathrm{~s}^{8}$, and Bernanke and Gertler (1990) showed that imperfect information in capital markets gave rise to a financial accelerator. ${ }^{9}$ In particular, Greenwald and Stiglitz (1993a) explained how shocks to a firm's equity base (resulting from a shock to the demand it faced, arising from any source) lead to reductions in both demand and supply, its demand for investment goods and its willingness to produce and its employment. There was an accelerator effect. The effects of shocks were amplified, not dampened. Greenwald and Stiglitz (1991, 2003a) show further amplification effects through similar disturbances to banks' balance sheets, resulting in potentially large changes in the supply of credit and the terms at which it is made available through the banking system.

\section{How do we explain persistence?}

The third question is, how do we explain the persistence of the effects of a shock? How do we explain that after the onset of a deep downturn, output and employment remain low? The losses in GDP after the 2008 crisis have been far greater than those associated with the misallocation of resources before crisis, as the economy remained markedly below the crisis level and its pre-crisis trend growth for a long period. $^{10}$ Yet, there are the same real assets (physical, human, natural capital) after the crisis as before. More recently, in the aftermath of the 2008 crisis, many have referred to the excess leverage in the economy. But even debt shouldn't matter: standard General Equilibrium theory says that there is a market clearing competitive equilibrium - with full employment. Debt simply is a matter of who has claims on society's resources. There is nothing in standard equilibrium theory that says that there are patterns of ownership claims that are inconsistent with full employment.

It should be clear that the source of persistence is not in the capital stock or labor supply (though eventually, extended periods of unemployment do have effects on human capital and extended recessions and depressions do have effects on the stock of physical capital). There is persistence in unemployment-and explaining why the economy does not quickly return to full employment is key.

\section{The Zero Lower Found is Not the Problem}

\footnotetext{
${ }^{8}$ Greenwald and Stiglitz (1987b, 1988a, c,d, 1990, 1993a, 2003), basing their work on models of credit and equity rationing (Stiglitz and Weiss, 1981, 1983; Greenwald, Stiglitz, and Weiss, 1984).

${ }^{9}$ The various models assume somewhat different financial frictions, i.e. some focus on borrowing constraints arising from costly state verification (Townsend 1979), others from those associated with adverse selection and moral hazard. Greenwald and Stiglitz in their series of papers also focus on those associated with equity markets. There can be marked differences in results, as we shall comment below. Thus, results based on models with costly state verification may not extend to other forms of financial frictions.

${ }^{10}$ In fact, as this paper goes to press, in many European countries, the level of GDP per capita is below the precrisis level, and even in the United States and the best performing European countries, GDP remains markedly below the level it would have been had trend growth continued. (See Stiglitz (2015c))
} 
Recent discussions have focused on the zero lower bound-the inability to lower nominal interest rates below zero. I believe the explanation does not lie (or does not lie just) in the zero lower bound (ZLB). The 2008 crisis was, in this respect, markedly different from the Great Depression, when prices were falling at an annual rate of $10 \%$. Then a zero nominal interest rate meant a real interest rate of ten percent, enough to discourage investment. ${ }^{11}$ In the recent crisis, prices were increasing at around 2 percent, so the zero lower bound meant a negative real interest rate of 2 percent. Some argued that if one could increase inflationary expectations-say by committing to an inflation target of $4 \%$-we could lower the real interest rate, say to minus 4 percent. Neither theory nor evidence suggests that such a change in the real interest rate would have restored the economy to full employment-even if one could have credibly committed to maintaining inflation at $4 \%$. (Moreover, if the underlying problem was the inability to change intertemporal prices through monetary prices, there was an alternative: changing them through taxes, e.g. through a schedule of changing investment tax credits and consumption tax rates.)

But even if part of the failure of the economy to be restored to full employment did lie in the ZLB, it is critical to understand what gives rise to the ZLB problem. Clearly, the underlying problem is the lack of aggregate demand, the result of liquidity-the ability to spend income-being in the hands of those who don't want to spend (or consume). Before the crisis, the bottom $80 \%$ of Americans were spending $110 \%$ of their income (on average). This was possible because banks were reckless in their lending; they believed too that the market value of houses represented their true value, so that lending against this collateral was safe. With the breaking of the bubble, the willingness of banks to lend decreased. So too did their ability, with the marked decrease in the value of their net worth. So too did the willingness of households and firms to borrow, as they saw their balance sheets contract. (All of these effects had been earlier analyzed in Greenwald and Stiglitz, 1993a, 2003.) As we shall see in the subsequent discussion, if models are constructed in which the economy will always be at full employment in the future and there are no distributional effects, then the possibilities for stimulating the economy today is constrained: more spending today can only be induced by changing intertemporal prices. ${ }^{12}$

\section{Pseudo-wealth}

Guzman and Stiglitz (2014, 2015a, 2015b) have provided another explanation: before the crisis, differences in views, e.g. about the likelihood of the housing bubble breaking, gave rise to bets (speculation), which led to the creation of pseudo-wealth - with both sides to the bet believing that they were going to win, both believed that they were wealthy, or more precisely, the aggregate perception of wealth was greater than true wealth. After the crisis, pseudo-wealth got destroyed. Indeed, there was

\footnotetext{
${ }^{11}$ These numbers, however, obscure important aggregation problems. The decline in the consumer price index was largely a result of enormous declines in agricultural prices and, to a somewhat lesser extent, housing prices. Manufactured goods prices declined, but to a much lesser extent. See Greenwald and Stiglitz (1987b).

${ }^{12}$ As always in complex intertemporal models, things are never quite so simple: if there were variations in future labor supply, it is possible that there could still be changes in lifetime income without changes in the interest rate. That might be the case, for instance, if the government provided a public good which was complementary with private consumption and a substitute for leisure. The standard models, however, do not allow for such subtleties.
} 
even negative pseudo-wealth: borrowers may have believed that what they would pay, in expected value terms, to the lenders was greater than the leaders believed that they would receive.

\section{Dynamics of adjustment}

If the real wealth of the economy after the crisis is not much different from that before the crisis, if the market equilibrium depended only on critical aggregate state variables like the state of technology, capital stock, natural resources, and the amount of human capital ${ }^{13}$, then the full employment equilibrium after the crisis would not be much different from that before. Thus, the magnitude of adjustments in wages and prices that would be required to attain full employment would not be that different; and with some degree of wage and price flexibility, full employment should quickly be restored. But if the economy before the crisis was supported by a bubble or pseudo-wealth or if there are large distributional effects ${ }^{14}$ then there can be large changes in aggregate demand at the previously prevailing wages and prices; and to restore the economy to full employment would require large changes in wages and price.

But at least in the short run, these wage and price adjustments in a decentralized market economy can, be destabilizing. Unemployment, an excess supply of labor, leads to lower wages, which reduces aggregate demand. Such changes are redistributive, but the increase in spending out of the increase in profits is less than the decrease in spending by workers; and this is especially so if they worry about their future income and face borrowing constraints. Defaults and expected defaults associated with deflation-because debt contracts are not indexed-worsen banks' balance sheets, and lead to a contraction in lending. ${ }^{15}$

Finally, an analysis of deep downturns has to be based on an understanding of why there is such suffering associated with them. If the decrease in hours worked were evenly shared, if there were full intertemporal and interstate smoothing, and if crises were not so persistent, then the social cost of economic fluctuations would be much less. Even in the deepest of downturns, say in Greece in the aftermath of the Euro crisis, output fell only around $25 \%$. If the downturn lasted only a couple of years, a reduction of $25 \%$ for two years out of a working life of 40 years, at a low discount rate would amount

\footnotetext{
${ }^{13}$ Even with the same people with the same education, the value of human capital can be lower after the crisis, as the structure of labor demand may change. Differences in skills reinforces the insights of pseudo-wealth theory: agent $A$ thinks the return on activity $X$ is relative large, compared to the return on activity $Y$; agent $B$ has just the opposite view. The shock may change their valuations in ways which result in a significant decrease in aggregate demand (at any set of wages and prices).

${ }^{14}$ The later discussion will identify several other reasons why there may be large changes in aggregate demand.

${ }^{15}$ This is partly a result of the fact that bankruptcies sare costly-they are not just redistributive-and partly a matter of accounting and regulation: with mark to market accounting, an increase in bankruptcy probability lowers banks' net worth, and forces a cutback in lending or an increase in equity. But deep downturns are not a good time to raise equity; existing shareholders are likely to feel that there will be excessive dilution of their ownership claims. They do not take account of the macro-economic externalities associated with the contraction in their lending (just as they do not take account of the macro-economic externalities associated with their excessive lending in the run-up to the crisis). But even in the absence of these accounting and regulatory constraints, the diminution in bank net worth would lead to a contraction in lending, more than offsetting the improvement in the balance sheet of the debtors as a result of the discharge in their debts.
} 
to a reduction in lifetime income of only around $1.25 \%$ - and most individuals could easily absorb such a change. But, of course, none of these assumptions are accurate: the reduction in hours worked is not equally shared-some individuals become unemployed, while others experience only a slight reduction in hours worked; capital markets do not allow easy intertemporal smoothing; there is no private market for interstate smoothing-and unemployment insurance provides only limited insurance. ${ }^{16}$ And, if there is mean reversion, it is limited: with deep downturns, the losses in output often appear permanent, with growth in the future occurring off of a diminished basis, and with hysteresis effects even affecting growth rates (e.g. because of the diminution of human capital, a result of the lower job experiences of young people). Thus, any meaningful theory of deep downturns must come to terms with these critical aspects of markets and market dynamics; Lucas' (1987) failure to do so explains why he has grossly underestimated the social costs of economic fluctuations.

\section{Three strands of theory}

In this part of the lecture, I will look at the three major strands of modern macro-economics-real business cycles (and related work); new Keynesian theories with rigid wages and prices; and alternative strands of New Keynesian economics, based on the work of Irving Fisher (1933) and Greenwald-Stiglitz. While each may have worked to help explain different historical episodes (oil price shocks, the Great Moderation and the early 90s), I will argue that only the third provides a convincing interpretation of deep downturns, such as the Great Depression and the Great Recession. After presenting these three strands, I will illustrate the differences by contrasting some key policy recommendations.

\section{A. Real business cycles (and related work) ( $1^{\text {st }}$ generation DSGE models) (RBC)}

The assumptions underlying this work, which dominated macro-economic analysis in much of the latter part of the twentieth century, are sufficiently well known that I do not have to recount them here. I will focus my attention on those which I believe are central to these models' failure to provide insights into deep downturns. Among the critical assumptions are: (a) exogenous shocks; (b) perfectly flexible wages and prices, which means that all markets clear-there is, in particular, always full employment (though there may be variations in the hours worked); (c) the perfectly flexible price system, together with inventories, dampens shocks (so that inventories are counter-cyclical); (d) all market participants have rational expectations; and there is common knowledge. There is, of course, still uncertainty; but there is no learning-in the way that learning is usually defined-and individuals have nothing to learn from each other. ${ }^{17}$ There are, of course, no betting markets-since individuals all agree about the probabilities of all events.

\section{Full equilibrium, with no unemployment}

Under the assumptions of the model, the economy is always in equilibrium-market acts as if there were futures markets going out infinitely far into the future and as if there were a complete set of

\footnotetext{
${ }^{16}$ See Stiglitz and Yun $(2005,2013,2014)$ for a more extensive discussion of the limits on the ability of insurance and loans to achieve full interstate and intertemporal smoothing.

${ }^{17}$ Of course, in the absence of uncertainty, there is nothing to learn. With uncertainty, there is, in principle, something that could be learned (e.g. forming better estimates of future variables), but the possibility of such learning is excluded by assumption from the analysis.
} 
Arrow-Debreu securities. Of course, neither of these assumptions are valid, and they make sense only in the context of one more very strong assumption: all individuals are identical. The representative agent model is, in this sense, more than just a simplifying assumption. With a representative agent model, it is conceivable that the individual could solve the infinite life-time model-could understand the transversality conditions and figure out the dynamic path consistent with them. With, however, a society with heterogeneous agents, each individual would have to solve a complicated infinite period general equilibrium problem-knowing the preferences of all other individuals and the production technology of all firms - obviating one of the basic presumed advantages of competitive markets, the ability to fully decentralize decision making (so firms only have to know prices and their own technology to know what to do). ${ }^{18}$

\section{The Problematic Nature of the Representative Agent}

But the representative agent model, as unrealistic as it is, brings with it three further problems which make it particularly unsuitable for analyses of deep downturns. First, there can't be any interesting problems of information asymmetries, that is, unless individuals suffer from acute schizophrenia; and it is hard to reconcile that assumption with the previous assumption of full rationality.

Secondly, financial markets are largely irrelevant. After all, who is lending to whom? And by the same token, the nature of the financial instruments is irrelevant. There is no one with whom one can share risk. There is no "matching" of risks with risk preferences. Thus, by construction, these theories have little to say about financial crises. (It is possible, of course, to "solve" this conundrum by assuming a small open economy, borrowing from abroad.)

And thirdly, distribution is not important; distributive consequences of shocks and policies do not matter.

\section{Policy implications}

The model has strong policy implications. Because, under the highly stylized assumptions, markets respond efficiently to exogenous shocks, there are no market failures, and hence no role for government. There is no unemployment: variations in employment are just variations in the amount of time that individuals spend enjoying leisure. There is something patently unrealistic about this interpretation of unemployment: normally individuals seem happy when they are enjoying leisure; but there is ample evidence (both from surveys and behavioral symptoms, such as suicides) that individuals are not happy in economic downturns, and especially so in deep downturns.

\section{Technology Shocks and Collective Amnesia}

These are but a few of the large number of unconvincing aspects of these models. Earlier, I noted others (e.g. the assumption that the shocks to the economy are exogenous, not endogenous). I note just one more: The shocks to the economy that these focus on are technology (or supply) shocks.

\footnotetext{
${ }^{18}$ One of the peculiar aspects of these models is that if they were true then market socialism would have worked. (See Stiglitz 1994.)
} 
Employment decreases when labor becomes less productive. Of course, while it is easy to explain positive technology shocks (we discover a new way of producing something), it is much more difficult to explain negative shocks. Has there been a bout of collective amnesia, such that we forgot what we knew? Was there an epidemic of amnesia in 1929 and the years following, so far undetected in medical records?

In spite of the implausibility of such negative shocks, such models continue to be used to explain economic downturns. Thus Kydland and Zarazaga (2002) purport to explain Argentina's 2001 crisis as the consequence of a negative technology shock within a RBC framework-as if there had been an epidemic killing off a large fractions of their engineers.

There is a further problem: typically, the timing is off. There was no major technology shock coinciding with any of the major economic downturns that could explain a perturbation of the magnitude observed. Of course, in models with forward looking agents with rational agents, as important as the shock itself is the news of the shock: when agents learn that technology in the future is going to be different from what they had expected. But this doesn't help; in some ways it makes explaining large perturbations even more difficult: there was no major news, no sudden change in expectations about future technology surrounding the onset of any of the major economic downturns.

But there is a still further problem: typically, a shift in the supply curve to the left would lead to higher prices. (The oil price shock has this effect.) But deep downturns are marked by deflation, not inflation. Something else must be going on.

\section{B. New Keynesian theories with rigid wages/prices (DSGE Generation II)}

These theories keep most of the assumptions of the Real Business Cycle models, and thus most of their flaws. They represent the minimal change in the conventional competitive equilibrium model required to get sustained unemployment.

Thus, like the real business cycle theories, they assume that the shocks to the economy are exogenous (and still mostly supply side shocks). And they continue to assume rational expectations. As we noted earlier, there was no exogenous event, or even news about previously unanticipated exogenous events that would be occurring in the future, that could explain the sudden decrease in economic output in 2008 or the marked shift in the economic "equilibrium".

\section{Nominal rigidities}

The main difference with real business cycles is the assumption of rigid wages and prices (and typically, it is nominal, not real rigidities, that are assumed). The consequence, of course, is that markets may not clear-in particular, the market for labor, so that there can be persistent unemployment.

But analyzing intertemporal models without market clearing is very difficult: in such models, the short side of the market dominates (that is, if demand is less than supply, equilibrium output is determined by demand). The regime that the economy is in at each date can affect the regime it is in other dates: they 
can be a large multiplicity of equilibria. Moreover, there are important income effects: an increase in aggregate demand at any date changes budget constraints, and has income effects at other dates, possibly causing a change in regime at those later dates. Beginning in the 1960s, a variety of versions of such models were studied by Gandmont, Barro and Grossman, and Stiglitz and Solow, amongst many others. But these models were not well suited to be a simple generalization of the RBC models.

Thus the new models typically assumed enough flexibility that markets cleared. The labor supply was assumed variable, so there were variations in the employment rate, though not in the unemployment rate. ${ }^{19}$ This by itself is a major limitation of these models in explaining deep downturns: a key issue, we suggested earlier, is the depth and duration of unemployment.

The major explanation of nominal rigidities was menu costs-a name which perhaps appropriately trivialized the explanation itself. With modern technology, reprinting the menu, to reflect changes in prices, is almost costless. More fundamentally, a shift in, say, the demand (or supply) curve for a perishable product necessitates either a change in output or a change in prices. A firm needs to look at these adjustments costs together, not separately. Typically, the costs of adjusting prices are an order of magnitude smaller than those associated with adjusting quantities. Thus, for perishables, menu costs simply cannot explain price rigidities.

For non-perishables, matters are different, for there is a third alternative: goods can be put into or taken out of inventories. One then has to compare those costs with the costs of adjusting prices or quantities. But this is a quite different problem than that posed in the menu cost literature. Greenwald and Stiglitz (1989) have argued that central to the analysis is uncertainty, including uncertainty about how other market participants will respond to a change in price or quantity. They explain how such uncertainty can explain nominal price rigidities.

Another strand of literature explaining nominal rigidities focuses on contract rigidities, e.g. in models with staggered contracts. Contracts may affect infra-marginal adjustments, but there is normally ample scope for marginal adjustments, and in "standard theories" (e.g. ignoring efficiency wage effects, which we discuss in the next subsection) those marginal adjustments should suffice to restore full employment, or at least to greatly reduce unemployment. ${ }^{20}$ In short, contract theory on its own provides an incomplete basis for explaining the nominal rigidities that could give rise to a sustained high level of unemployment; but contracting rigidities can play an important role in a more general theory.

Still another market imperfection commonly introduced (in combination with the previous) is monopolistic competition, through the use of Dixit-Stiglitz preferences. There is an art form in

\footnotetext{
${ }^{19}$ There are models, of course, with costly search, where there can be frictional unemployment. This lecture is concerned with deep downturns, where the level of unemployment goes well beyond that which can be described by search frictions. As we explain later, there are other labor market frictions which are relevant.

${ }^{20}$ Those firms that are in the process of setting wages and prices do so knowing that they will not be able to adjust them for a certain length of time, and hence have to take into account economic conditions in those future periods. Thus, if the economy is adjusting towards eliminating unemployment through lowering wages and prices, this induces those firms able to adjust to lower them more than they would if they were maximizing profits only looking at current wages and prices.
} 
introducing distortions; they have to be simple enough to be tractable, plausible, and yet not so simple that there would be a simple policy by which government could undo the distortion and return the economy to the RBC "ideal." Because of the distortions, of course, the market equilibrium is not in general efficient, and so in principle there is a role for government policy.

But the problem in deep downturns is not price rigidity but deflation!

The focus on price rigidities seems strangely out of keeping with the major pre-occupation in deep downturns with deflation. Today, central bankers in many countries are worried about deflation. In Japan, the objective of inflation targeting is to convince the market that there will be inflation in the future-and to bring an end to the era of deflation, which it is believed has contributed to Japan's weakness over the past two decades. In the Great Depression, prices fell at $10 \%$ a year-it is hard to call that "nominal rigidity."

In early versions of New Keynesian models, financial markets were assumed to work efficiently; in later versions, financial frictions were introduced (see, e.g. Bernanke and Gertler (1990)), but these never came to play the central role that they played in the alternative strand of New Keynesian models discussed in the next sub-section-not surprisingly, because it is hard to have an interesting financial market in a representative agent model; and a major source of financial frictions are information asymmetries, which again can't arise easily within a representative agent model. Of course, as we noted in the case of RBC models, one can introduce financial markets in a small open economy model; but even then, such models have to be carefully crafted to avoid distributional effects. If there is an open economy with equity markets, then changes within the economy can redistribute income to foreign owners, with macro-economic consequences.

Price and wage rigidities, as we have noted, were at the center of the model, so that as a result financial markets and frictions within those markets were largely a side-show, and not elaborated upon. There were not, for instance, banks, and there was not as a result an analysis of how monetary policy affects banks, and through the banks the supply of credit. Additional complications were introduced as Ptolemaic exercises, as it became increasingly evident that these models did not provide a good description of what was going on. In particular, financial markets and their imperfections do not, in this strand, play the central role that they do the models to which we now turn.

\section{Alternative strands of New Keynesian}

Even this brief description of the two dominant strands of macro-economic literature that I have just described should make it clear that these models do not provide a sound basis for understanding deep downturns. They are not constructed to provide answers to the three central questions posed in the first part of this lecture; and they do not do that.

There are several alternative (and in some ways complementary) strands to a literature which I should, for lack of a better term, refer to as finance based New Keynesian models. Much of my discussion will 
focus on the Fisher debt deflation model (revived by Greenwald-Stiglitz in 80's, early 90's) ${ }^{21}$, but I will have a few words to say about the important work of Minsky (1992).

I note that the DSGE models with fixed money wages and prices seem to have successfully appropriated for themselves the title "New Keynesian." There is a natural sense in which Hicks' price and wage interpretation of Keynes was extended to these models. But Hicks modelled only some aspects of Keynes' General Theory. I believe that the models discussed here, where wages and prices are flexible, are as or more consistent with the central insights of the General Theory, and thus, while they have little to do with the New Keynesian model with fixed wages and price, they fully deserve the epithet New Keynesian.

\section{Financial frictions}

In this work, the financial sector is central: it is the source of "rigidities" that help explain the amplification and persistence of shocks, and it is the source of the perturbations to the economy.

The models focus on several financial market imperfections, several deviations from the perfect markets paradigm. There can be credit and equity rationing. Firms may not be able to borrow; the amount they can borrow may be limited by their collateral or their net worth; they may not be able to raise new equity-or more precisely, there may be a high cost from the dilution of existing shareholders from doing so. Much of the lending in the economy is mediated by institutions (banks), which themselves face credit and equity constraints, as well as regulatory constraints.

Moreover, financial (debt) contracts are typically not indexed to inflation (or other relevant shocks.) That means that when a firm experiences a negative shock to its demand, leading to lower prices, its revenues decrease, but what it is obligated to pay remains unchanged. ${ }^{22}$ Capital market imperfections explain why a firm cannot easily raise additional equity to offset the reduced equity resulting from the reduced revenues.

Moreover, risk markets-insuring firms against the important risks which they face-simply don't exist.

Each of these market imperfections, in turn, can and has been explained in terms of imperfect, costly, and asymmetric information, transactions costs, the costs of verifying states of nature, costs of bankruptcy, and the difficulties and costs of writing and enforcing contracts. ${ }^{23}$

Macro-economic externalities are pervasive

\footnotetext{
${ }^{21}$ See the works listed in the references. Two articles providing a broad survey of our perspective are Greenwald and Stiglitz (1988b and 1993b). See also Greenwald and Stiglitz (2003a).

${ }^{22}$ As we explain below, this argument even applies to disinflation-lower rates of wage and price inflation than were anticipated. For then, the firm's balance sheet will be weaker than it was anticipated to be.

${ }^{23}$ On credit rationing with and without endogenous collateral constraints, see, for instance, Stiglitz and Weiss (1981, 1983, 1986); on equity rationing, see Greenwald, Stiglitz, and Weiss, 1984 and Maljuf and Myers, 1984; on other implications of imperfect information for finance, see Stiglitz, 1982; on costly state verification, see Townsend, 1979; on the role of bankruptcy, see, e.g. Stiglitz $(1969,1972)$, Hellwig, 1977, and Greenwald and Stiglitz (2003); and on debt enforcement, see Eaton and Gersovitz 1981 and Eaton 1986.
} 
Whenever there is an incomplete set of risk markets and imperfections/asymmetries of informationthat is always-markets are not (constrained) Pareto efficient. (Greenwald and Stiglitz, 1986.) As we explain, pecuniary externalities matter. Systematic micro-economic externalities add up to macroeconomic externalities. These are pervasive: As Korinek (2011) and Jeane and Korinek (2010) point out, there can be, for instance, too much indebtedness or too much borrowing from abroad.

\section{Balance sheets matter}

In the standard neoclassical theory (which underlies both Real Business Cycle Theory and the New Keynesian rigid wage and price models), balance sheets don't matter; neither does a firm's cash flow. Investments are based on expectations-if the expected present discounted value of the profits associated with a project is greater than the cost, the project will be undertaken. There are perfect capital markets - there is no credit rationing-and perfect risk markets. Bankruptcy is simply not a matter of concern.

But if firms cannot insure themselves against risks that matter (for instance, that the price of their product will fall) and they cannot (easily) raise new equity, then they will act in a risk averse manner, and this affects every aspect of their behavior. ${ }^{24}$ In particular, as a firm expands, it must borrow more; and that means that if the firm expands, there is a higher probability of bankruptcy. Now, part of the marginal cost of producing more is the marginal bankruptcy cost. So too, if the balance sheet of the firm shrinks, it must borrow more to produce the same amount that it otherwise would have produced; but, that means the bankruptcy probability is higher.

Hence, a shrinkage of the firm's balance sheet means that firms will not wish to produce as much, employ as many workers, or engage in as much investment. (Greenwald and Stiglitz, 1993a.) There are effects both on demand and supply.

\section{Redistributions matter}

A corollary of these capital market imperfections is that redistributions have real effects-and this would be true even if all individuals have the same preferences, but is even more so, given that they don't. Changes in prices that on the face of it might look simply redistributive have real aggregative effects. In a closed economy, for instance, the increase in the price of oil improves the balance sheet of oil producers and hurts those of users, and these two effects might appear to cancel-and they do in the standard perfect markets models. But if there are capital market imperfections, then the changes in, say, demand for investment and employment by those who gain may be far less than the reductions on the part of those who lose.

\footnotetext{
${ }^{24}$ Firms may act in a risk averse manner for other reasons: managers' long term compensation depends on how well the firm that they are managing does; they cannot fully diversify out of this risk. See Greenwald and Stiglitz (1990a) and Stiglitz (1982).
} 
By the same token, one might have thought that not indexing debt contracts has only a distributive impact: the lenders gain (in the face of a negative shock) and the borrowers lose, and these effects too would just cancel. But they do not.

\section{Banks as firms}

In these models (unlike the two other strands just discussed) the financial sector is important, and financial institutions-banks in particular-matter. Banks are specialized institutions that gather and process information about borrowers' credit worthiness and monitor debtors to make sure that they can pay back what is owed. There is a system of accountability, far better than with the shadow banking/securitization model: if a bank makes a loan and it turns bad, the bank bears the consequence. Hence the bank has strong incentives to do a good job on due diligence.

Banks borrow money (accept deposits) and, after ascertaining the credit worthiness of different potential borrowers, lend it out. The more they lend, the more they have to borrow, and this increases the probability that they go bankrupt (unless they were to increase their capitalization proportionately). The theory of the risk averse firm described in previous paragraphs applies just as well to the theory of the risk averse bank.

Accordingly, changes in bank balance sheets have first order effects. Changes in bank balance sheets affect the ability and willingness to lend. This affects credit availability and the terms at which credit is available. As Stiglitz and Weiss (1981) pointed out, credit rationing is not a phantasm. Indeed, everyone in the financial crisis talked about a liquidity crisis-firms and banks couldn't get access to credit at any interest rate. Remarkably, in this, the onset of the deep downturn that was to become the Great Recession, even those who had seemingly believed in perfect markets were willing to talk about the lack of credit availability-something that was fundamentally inconsistent with the standard paradigm. The evidence of credit rationing was overwhelming.

\section{Why deflation-or disinflation-a problem}

The Fisher/Greenwald/Stiglitz theory explains why deflation can be a source of problems. The real value of what firms owe and have to pay on their debts increases. This diminishes their net worth from what it otherwise would have been. In effect, deflation increases a firm's leverage. And the theory explains why leverage matters. At the same time, as we have noted, the gains to the creditors do not offset the losses to the debtors. In the representative agent model without financial frictions, the increase in leverage would not matter.

It should be noted that this argument even applies to disinflation-lower rates of wage and price inflation than were anticipated mean that the balance sheet is weaker than anticipated and, therefore, that output, employment, and the demand for investment goods are all lower.

\section{Why the absence of indexing matters}

This discussion should have made clear why the absence of indexing of debt contracts matters so much. The absence of indexing in itself can lead to lower employment and investment, in the face of 
bankruptcy costs; and this can help explain the amplification of shocks as well as persistence. For as firms borrow more, the probability of bankruptcy increases, and they take that into account in making production and investment decisions. An adverse shock which lowers net worth induces, as we have noted, less investment and production on the part of each firm-and when such individual decisions are aggregated throughout the economic system, they lead to overall lower output and employment. A small shock to net worth can have a macro-economic effect which is a multiple of the original shock. And because balance sheets cannot be restored instantaneously (indeed, it typically takes a considerable period of time, especially as production is scaled back), and because firms will be reluctant to raise new equity (even if they can), the effects of a shock may last a long time.

\section{Balance sheet recessions}

Thus, the Greenwald-Stiglitz (1993a) model provides an explanation of balance sheet recessions. (Many have suggested that the 2008 recession is a balance sheet recession. ${ }^{25}$ ) There are three critical aspects of a balance sheet recession: (a) A shock which leads to an unanticipated worsening of the balance sheets of many firms in the economy. (b) The response to the worsening of the balance sheet: $a$ contraction in economic activity; and (c) A slow "healing" of balance sheet-necessary and sufficient for the restoration of the economy to full employment.

The shock can be a price level shock (contractionary monetary policy leads to overall lower prices, meaning that the real value of what the firm owes has increased); a demand shock to a particular category of goods (individuals shift away, at least temporarily, from buying large cars); or a supply shock (the price of oil increases.)

Greenwald and Stiglitz then describe the response to the worsening of the balance sheet. There are both demand and supply side effects. Firms will not wish to produce as much, employ as many workers, or engage in as much investment. As we have noted, all of this is quite different from the standard neoclassical world, where there are neither the demand nor the supply side effects; and the difference is even greater with the representative agent models, where there aren't any redistributive effects. Here, a relative price shock which strengths the balance sheet of some firm and weakens that of another by exactly the same amount still has real effects on the aggregate equilibrium.

Central to the notion of a balance sheet recession is the idea that the adverse impacts on the balance sheet cannot be undone overnight simply by raising more equity. The equity in the firm has to be rebuilt, through retained earnings, and this is a slow process. And that is a key reason for the persistence of downturns.

But, as I discuss below, truly deep downturns are more than balance sheet recessions: they can persist even after balance sheets are largely restored.

\section{Risk perceptions and confidence}

${ }^{25}$ See, in particular, Koo (2011). 
In the standard model, confidence and the extent of uncertainty matters little: because risk is diversified throughout the economy (through perfect insurance markets), what matters is the mean return. But in these New Keynesian models, risk matters a great deal. A mean preserving increase in risk increases the probability of bankruptcy, leading to results similar to those that arise from a balance sheet shock.

This provides another channel through which amplification and persistence occurs: after the initial adverse shock, unless active government policies prevent a deep downturn, uncertainties increase. No firm can be sure whether its customers or suppliers will survive. A bankruptcy of any of its trading partners poses the risk of another negative balance sheet shock.

Indeed, in an interlinked economy, the probability of the bankruptcy of one firm leads to an increase probability of the bankruptcy of its trading partners, but this leads to an increased probability of the bankruptcy of those firms trading partners. The disruption emanates through the economic system.

(With the bankruptcy of one firm depending on firms with which it is interconnected, we have a complex general equilibrium system, which, with bankruptcy costs, has only been solved recently. (Roukny, Battiston, and Stiglitz, 2015). ${ }^{26}$ )

\section{Systemic Bankruptcy}

Bankruptcy itself has real societal costs. Much of the information in our society is embedded within corporations. The bankruptcy of an enterprise leads to the loss of organizational and informational capital-a negative shock to the economy, with effects similar to those associated with the negative productivity shocks assumed in real business cycle theory, but which are far more plausible. And of course, the magnitude of these and their consequences depends on the organizational structure of the economy and on economic policies.

\section{Hysteresis effects and persistence}

These real consequences of bankruptcy are also part of the explanation of persistence, part of the reason that there are significant hysteresis effects.

When I was chief economist of the World Bank, during the East Asia crisis, we had many disputes with the IMF. As the crisis first broke out in Thailand in July 1997, the IMF wanted to respond with its usual recipe, jacking up interest rates, intended to prevent the collapse of the currency. We were worried that with evidence that the Thai economy already weakening, the increase in the interest rate would exacerbate the economic downturn; and we feared that the hoped for positive effects would not be felt-the increased uncertainty about the weakening economy to which the higher interest rate would contribute could even exacerbate capital outflows, worsening the fall of the Thai Baht. We were afraid too that the higher interest rates would lead to the bankruptcy of a large number of firms. The IMF's response was that we shouldn't worry: if our analysis was correct (and evidence that that was the case mounted), they would reconsider their position, reversing course and lowering the interest rate. But I

\footnotetext{
${ }^{26}$ Earlier, Eisenberg and Noe (2001) provided a solution without bankruptcy.
} 
argued that there are important hysteresis effects: the firms that are forced into bankruptcy at the high interest rates do not suddenly become unbankrupt when interest rates are lowered. Though the IMF prevailed at the moment-imposing their usual combination of high interest rates and austerity, our analysis proved totally correct: the policies brought on a deep recession, with a large fraction of the loans becoming non-performing and a large fraction of firms not being able to pay what was owed.

Just as it takes time to restore firm and bank balance sheets, it is even harder to create new firms, to replace the firms that have been lost. There are analogous effects on human capital: those whose education is interrupted by a downturn typically do not resume their education when growth resumes; the loss in human capital associated with the on the job learning that did not occur simply because large numbers were not on-the-job is never recouped. ${ }^{27}$

\section{SME Lending}

These models also help us understand better some of the details of the current and similar downturns. First, investment and employment in small and medium sized enterprises was particularly hard hit, both in the United States and Europe. SMEs are particularly dependent on banking-information imperfections preclude access to capital markets for most SMEs. SME lending in turn is linked to regional banks, not a surprise given the importance of local information. ${ }^{28}$ Thus, it made a difference to aggregate lending where money was pumped into the system-whether the big banks had their balance sheets restored, or the smaller and regional banks were helped. (In the 2008 bailouts, neither the Administration nor the Fed grasped this. They worried about systemically significant banks. But collectively, the smaller banks are systemically significant. Too little money went to help the community and regional banks, part of the reason that SME lending remained depressed for so long.)

Of course, to understand how policies will affect lending, especially to small and medium sized enterprises, a theory of banking is required. ${ }^{29}$ The link between what monetary authorities do with the changes in the lending behavior of banks has to be understood. It is remarkable that most central banks used models with no banks: under these models, if they were correct, central banks might not even have come into existence.

\section{Securitization}

But while the standard models didn't explain lending by banks well, neither did they do a good job explaining what happened to non-bank lending, the vast securitization market that was at the center of the crisis. They simply assumed that markets worked well, that risks had been diversified, and these improvements in risk management were given much of the credit for the "great moderation." In fact, markets were not working well, and diversification may have made matters worse, rather than better.

\footnotetext{
${ }^{27}$ This is part of the missing capital that helps explain why, after a crisis, GDP remains well below the pre-crisis trend line. See Stiglitz (2015c).

${ }^{28}$ Greenwald and Stiglitz (2003) emphasized this.

${ }^{29}$ The purpose of our 2003 book was to provide such a theory.
} 
There were, in fact, fundamental flaws in the model of securitization (which helps explain why the US government still has a central role in the American mortgage market, underwriting more than $90 \%$ of mortgages, more than eight years after the breaking of the housing bubble.) Information is a public good, and, as Sandy Grossman and I long ago pointed out (Grossman-Stiglitz, 1976, 1980), if financial markets were informationally efficient-in the sense that information was efficiently conveyed through prices, there would be no incentive to gather information. Markets must necessarily be informationally inefficient. Some thought one could "solve" this problem with credit rating agencies. But the CRA were paid by those that they were rating: there was a race to the bottom. Their performance was dismal. There is, in fact, no easy solution - there is no viable private alternative. Banking provides an answerthose who make a loan bear the consequences of any mistakes. ${ }^{30}$

\section{The structure of credit networks and optimal diversification}

Before the crisis, the standard models paid no attention to what happened within the financial sector. These were details of no moment, or so they argued. One could describe the financial sector by a representative firm, just as one could describe the household sector by a representative household. But, of course, what happens inside the financial sector matters a great deal. Financial interlinkagesfinancial networks, and their structure-matter. A collapse of one firm (Lehman Brothers) might have led to the collapse of the entire financial sector, had the Federal government not intervened.

There were two critical analytic mistakes. The first is related to the macro-economic externalities discussed earlier: if there are externalities exerted by one financial agent on others which they don't take into account, then the behavior of the financial sector cannot be described well by a model with a single (rational) financial firm.

The second is related to the hypothesis that diversification unambiguously improves matters. That is the case in models where all relevant functions are convex. But non-convexities are pervasive: there are, for instance, bankruptcy costs. Moreover, a firm which faces a negative shock may find itself paying higher interest rates-leading to a process of trend reinforcement. In such a situation, diversification may make matters worse. (No one would suggest that the response to a contagious disease is diversification-spreading those who have been exposed to the disease around the world; but that, in effect, was what diversification implied.)

Ironically, the advocates of globalization and financial integration argued for the virtues of diversification before crises; but afterwards, they shifted their attention towards contagionemphasizing in effect how interlinkages could lead to the spread of a problem in one country to others.

\footnotetext{
${ }^{30}$ Financial markets thought that they had found a good solution to the moral hazard problem that arises when the parties originating mortgages and packaging them differ from those who ultimately hold the assets: the originators and the investment banks that put together the securitization packages made warranties and representations concerning the mortgages; any mortgage that was not as represented could be put back to the originator and/or investment bank. In the aftermath of the crisis, it became evident that there was widespread fraud, and the originators and investment banks refused to honor the contract. In some cases, after very expensive litigation, they were forced to do so by the Courts. These critical aspects of markets are not embraced by the standard models.
} 
Intellectual consistency should have forced them to take into account these risks ex ante, before the crisis. In fact, one can show that there is an optimal degree of interlinkage (diversification); and that after a crisis, it may be desirable to sever linkages-imposing capital controls. ${ }^{31}$

\section{Financial sector imperfections and the creation of volatility}

Financial market imperfections are important not only because they help explain amplification and persistence. They are also an important part of the explanation of the source of the disturbance: the breaking of the housing bubble and the consumer spending bubble to which it had given rise.

Kindleberger (1978) and Minsky (1992) both stressed the role of bubbles as a source of economic fluctuations. While there is some research suggesting that bubbles can exist even in the presence of rational expectations ${ }^{32}$, a closer look at this bubble, as well as earlier bubbles, suggests that irrational expectations as well as massive fraud $^{33}$ played a central role. It seems a misuse of intellectual resources to dwell too long on the counterfactual: could there have been a crisis if all individuals had acted rationally and had rational expectations.

But as modern behavioral economics has emphasized, even if individuals are not fully rational, their behavior can be predictable. ${ }^{34}$ Thus, Minsky emphasized that as markets became better at managing risk, individuals and firms might undertake more risk, so that the stability of the system might not improve much. ${ }^{35}$ If they became overconfident in their ability to manage risk (as seemed to be the case with some of our policy and financial leaders), then the system might become even more unstable.

Thus, we can and should study not just how markets might behave if everyone had rational expectations and common knowledge, but how they actually do behave-and how policies (regulations) can affect that behavior. It might not have been rational for investors, seeing returns on safe assets fall with loose monetary policies, to "grab for yield." (Standard theory would have predicted that the lower returns would have led to more, not less, risk averse behavior.) But if investors systematically do so, then we need to design countervailing policies.

By the same token, it might not have made sense for markets to shift so much risk associated with variations in interest rates to homeowners ${ }^{36}$, but given these failings in mortgage markets, it makes sense for government to impose regulations to prevent the adverse macro-economic consequences.

\footnotetext{
${ }^{31}$ For early discussions of bankruptcy cascades-how the failure of one firm can lead to that of others-see Allen and Gale, 2000 and Greenwald and Stiglitz, 2003. On optimal diversification, trend reinforcement, the design of credit networks, and the potential desirability of credit controls, see Stiglitz (2010a, 2010b) and Battiston et al 2007, 2012a, 2012b, 2013; Gallegati et al 2008; Haldane (2009) and Haldane and May (2010).

${ }^{32}$ This includes work on sunspot equilibrium.

33 See the earlier discussion in the context of securitization. In a sense, it is hard to reconcile fraud with rational expectations: if there were even a small expectation of such fraud, individuals and firms would not have entered into the contracts. See Greenwald and Stiglitz (1992). Kindleberger (1978) notes that similar problems occurred in many of the other bubbles.

${ }^{34}$ See, for instance, Ariely (2010).

${ }^{35}$ See also Greenwald, Stiglitz, and Weiss (1984).

${ }^{36}$ Even Greenspan did not seem to understand the basic principles of the allocation of risk. See Stiglitz (2010).
} 
Whether rational or not, there are large macro-economic consequences to these behaviors, and thus, there is a need for government regulation.

Going forward, I believe an important part of the research agenda should be trying to understand better the way our economic system creates volatility. Understanding the creation and breaking of credit and asset bubbles is part of the story-a part in which we already have a good sense of how deregulation and loose monetary policy can facilitate the creation of such bubbles. But there is more: Earlier, I described ongoing research on fluctuations in "aggregate" expectations of future wealth-the process of pseudo-wealth creation and destruction, which can give rise to fluctuations in aggregate demand. Creating new opportunities for gambling (trading on the basis of differences in probability judgments)while defended on the grounds that doing so was "completing markets," making the economy closer to the Arrow-Debreu ideal-actually can increase volatility. (Guzman and Stiglitz, 2014, 2015a, b.)

Before turning to the contrasting policy positions of these various strands of macro-economics, I want to address three other critical differences between this line of work, and the two described earlier.

\section{Disequilibrating dynamics}

There is another reason suggested by these theories for the persistence of downturns: Short run adjustments may be disequilibrating. Lowering real wages-which typically is the decentralized market's response to unemployment and is normally thought to be required if the gap between the demand and supply of labor is to be reduced-lowers real aggregate demand, exacerbating problems of unemployment.

But there are other reasons that even a lowering of nominal wages and prices may exacerbate the economic downturn, linked to the financial market failures already noted: Lowering nominal wages and prices increases leverage of households and firms, lowering aggregate demand.

The increased leverage can, in turn, increase bankruptcy probabilities, leading to the destruction of information and organizational capital, and increasing uncertainty, with both supply and demand side effects. This, in turn, leads to weaker banks, decreasing lending and increasing interest rates charged by banks (increasing the spread between the $T$ bill rate and the lending rate.)

\section{Real" rigidities matter}

In real business cycle theory, there are no rigidities, so that markets always clear. By contrast, we have argued that especially in the context of deep downturns, it is obvious that neither the labor nor capital markets "clear": there is both unemployment and credit rationing (liquidity constraints bind). In the New Keynesian analysis, attention is centered around nominal rigidities. In our earlier discussion, we explained why some of the traditional explanations of these nominal rigidities are not convincing. But more importantly, it is real rigidities that prevent markets from clearing. Even if there were nominal wage rigidities, if prices were flexible, real wages could adjust to clear markets. 
Imperfections of information can give rise to real rigidities, both in labor and capital markets. ${ }^{37}$

\section{Real rigidities and decentralized adjustment processes}

Slow processes of adjustment ${ }^{38}$ too can lead effectively to real rigidities. In a decentralized economy, wages fall in response to unemployment (due to lack of clearing in the labor market), and then prices fall in response to the gap between aggregate demand and supply (due to lack of clearing in the product market). Then net effect is that real wages change little. (Solow and Stiglitz, 1968.) ${ }^{39}$

\section{Labor market frictions}

There is one more important source of real rigidity in the economy-one about which the standard excessively aggregated macro-models can have little to say: individuals can be "trapped" in one sector, unable to make a transition to a higher wage job elsewhere, either because they cannot afford to obtain the requisite skill or because they cannot afford the moving costs. Capital markets are imperfect, and those needing to move are often in a poor position either to afford these expenditures on their own or to borrow. In some cases, the sectors out of which individuals need to transition are, in a sense, successful: productivity has increased so much that the demand for labor has decreased. That was the case in agriculture in the first part of the twentieth century, and is the case in manufacturing today. Markets on their own do not manage such structural transformations well. ${ }^{40}$

Is the current recession more than a balance sheet recession?

In some ways, we are in a similar situation today. The enormous increase in productivity in manufacturing-beyond the increase in demand-means that global employment will be going down; and changing comparative advantage means that an increasing fraction of that employment will be in developing countries and emerging markets. In the United States and Europe, there needs to be a structural transformation from manufacturing to the service sector, and again, markets do not manage such transformations smoothly on their own. Making matters worse is the fact that two of the service sectors into which resources will be moving, education and health, are sectors where government, understandably, plays a big role. But with cutbacks in government spending, the public sector will not be able to play the role that it should in moving the economy from a manufacturing to a service sector economy.

That is why I believe that the current downturn is more than a balance sheet recession. Even when balance sheets are restored say to pre-crisis levels, the economy will not be back to health: the economy was not in fact health in 2007 and 2008 before the crisis. What sustained the economy then

\footnotetext{
${ }^{37}$ There is a large literature on efficiency wages, dating back to Stiglitz (1974) and Shapiro and Stiglitz (1984).

${ }^{38}$ Explained in part by uncertainty and risk aversion (Greenwald and Stiglitz, 1989).

${ }^{39}$ Moreover, differences in the processes governing price adjustments in different sectors in a decentralized economy can give rise to significant allocative distortions. See Stiglitz (1999).

${ }^{40}$ More generally, fixed and especially sunk costs of hiring workers also can give rise to real rigidities in labor markets, leading to unemployment. See Greenwald and Stiglitz (1987b, 1995).
} 
was an unsustainable bubble. In the absence of the bubble, aggregate demand would have been insufficient to maintain the economy at full employment.

\section{Rational Expectations}

We noted the central role that rational individuals with rational expectations played in the first two strands of economic research. I believe that rational expectations provides a poor guide to understanding macro-behavior.

There are some contexts in which rational expectations might make sense: a static society, in which the only source of variability is weather. In such a world, individuals might eventually learn the full consequences of each possible observable state of nature (though given the number of such states, it is plausible that they would in fact use simpler heuristics), and base their behavior rationally on such expectations.

But today, even in this simplistic context, rational expectations would make no sense: climate change means that we are experiencing weather patterns not seen for perhaps millions of years, and not only are memories limited, but man was not even around the last time weather was similar.

The world is always changing, so that it is not even clear what is entailed by rational expectations. The structure of the economy today is markedly different from what is was not that long ago, and economic policies that are being tried today are different from those that were even tried in the past. How could a rational expectations model make sense in such a situation?

In particular, there hasn't been a downturn as deep as this one for 80 years. The world 80 years ago was markedly different-with different politics, different beliefs about the economy, a different economic and financial structure.

In rational expectations models, everyone has same beliefs. But as we have argued, divergences in beliefs are of first order importance for understanding markets and macroeconomic behavior. This helps explain the large diversity of interpretations of events and policies. Even now, there are disagreements about magnitudes of multipliers. Some of these disagreements are because some economists are working with the wrong model. It should be obvious that any model that assumes that labor and capital markets clear is not going to provide insights into a deep downturn. Inferences based on models estimated in "normal" times are of little relevance in deep downturns. In normal times, the economy is close to full employment, so that an expansion of government spending crowds out private spending. But this is not so when there are large amounts of underutilized resources, as in a deep downturn.

In RE models, there is no learning, no problem of assessing whether we are experiencing an extreme outcome in an old regime, or whether we have moved into a new regime. But such learning is, I believe, central to behavior of economic agents. (Guzman, 2013.) 
Many critical aspects of what went on in the economy in the run up to crisis cannot be reconciled with rational expectations behavior on the part of large fraction of economic actors-although there were often a few who made some money by exploiting seeming irrationality on the part of others. But these did not suffice to prevent the creation of a major bubble. ${ }^{41}$ (Thus, the argument that the economy acts as if everyone were rational-because those that are can "arbitrage out" any inefficiencies created by those who are not, was patently wrong.)

This is more than just a statement that the crisis was not "expected". ${ }^{42}$ As I noted earlier, the design of mortgages did not represent a "rational" and efficient system of risk sharing. ${ }^{43}$ Moreover, the dominant market ethos seemed predicated on the belief that housing prices could increase, seemingly forever, unabated. But it should have been obvious that it was virtually inconceivable that housing prices/real estate prices could continue to grow: there were limits on spending on housing (especially given the stagnation in incomes of so many Americans) and there is a virtually unlimited supply of land in Nevada desert, limiting the extent to which land prices there could have increased. It was thus remarkable that so many of our economic leaders, including the chair of the Federal Reserve, seemed unconcerned that there might be a bubble.

\section{Contrasting Elements}

While the three strands of macro-economics that we have described share much in common, I hope that the above discussion has highlighted some of the important distinctions. There are several in particular to which I wish to draw attention, and which will play an important role in the policy discussion to follow.

Deep downturns are a manifestation of deep and pervasive market failures-deviations from the standard competitive equilibrium model which underlies real business cycle theory. Markets fail in many ways, and the strand of New Keynesian model emphasizing nominal wage and price rigidity probably has identified one such market failure, but perhaps not the most important one. I have suggested that the alternative strand of New Keynesian models emphasizing financial sector imperfections may be more relevant, at least for deep downturns. Indeed, the third strand emphasizes that the central problem confronting economies facing deep slumps may not be price rigidities, but price flexibilities. The current worries about deflation are justified. Economies in which wages and prices are less flexible perform better.

\footnotetext{
${ }^{41}$ More generally, it can be shown that it is easy to have bubbles consistent with short run rational expectations so long as there are not futures markets going out infinitely far into the future (which there obviously were not), or equivalently, so long as there is not perfect foresight extending infinitely far into the future. See Hahn (1966) and Shell and Stiglitz (1967).

${ }^{42}$ If, of course, a crisis had been widely expected (at some earlier date), then consumption would have fallen at that earlier date-and the downturn would have occurred at that earlier date.

${ }^{43}$ See the earlier comments on variable rate mortgages and the references cited there.
} 
RBC models emphasize technology shocks. In the New Keynesian models of either variety, monetary policy shocks can also have important consequences. ${ }^{44}$ But the first two strands, with their emphasis on rational expectations, rule out the most important source of fluctuations: Deep downturns are caused by shocks to the economy created by the economy itself. The behavior giving rise to the shocks typically is associated with irrational behavior, and even when such irrationality is exploited by rational actors, they cannot fully undo the effects.

Finally, New Keynesian models with some price rigidities but with sufficient wage flexibility such that there is full employment, even if they might be able to explain movements in output and employment, have little to say about one the central variables of concern in deep downturns, unemployment. ${ }^{45}$

One consequence of the pervasive market failures is that there are large macroeconomic externalitiesthe application at the aggregate level of the pervasive market externalities arising in economies with imperfect information and imperfect risk markets discovered by Greenwald and Stiglitz (1986). Macroeconomic externalities help explain both amplification and persistence. While these effects and their implications (e.g. for multipliers) was originally studied in the context of New Keynesian models with financial frictions, similar results obtain in models with price rigidities. (Farrhi and Werning (2015).)

Deep downturns are often related to problems in the financial sector. (One has to be careful, however, to avoid the superficial reading of data which suggests that financial crises are different-they last long and are deeper. For an example, see Rogoff and Reinhart, 2009. A deep downturn, whatever its origins ${ }^{46}$, will eventually affect the financial sector as borrowers will be unable to pay; and when the downturn is deep enough, there will be a financial crisis in the absence of government intervention. In such a situation, the financial sector may be an important part of the process of amplification and persistence; but the statement that downturns involving a financial crisis are deeper and last longer may be nothing more than a tautology, saying nothing more than that deep and prolonged downturns are deep and prolonged.

The financial sector in turn cannot be understood within a representative agent model; information asymmetries and incomplete markets are central. Macro-economic externalities arise especially in the financial sector and highlight why one needs to study carefully the structure within the financial sector

\footnotetext{
${ }^{44}$ There are also some models which introduce demand shocks of another kind (Lorenzoni, 2006, 2011). Consumers' and firms' expectations are based on noisy public sources of information (a public signal). The noise component in this signal (i.e. the "news shock") causes aggregate mistakes in agents' expectations about productivity. These mistakes lead to deviations of output from its natural level, which have the typical features of aggregate demand shocks. But underlying the analysis is a technology shock, on which is overlaid imperfect information. It is not plausible that such demand shocks played an important role in recent fluctuations: as expectations of increased productivity grew in the late 90's, there was not a boom in demand, except for that produced by the housing bubble; and the slowdown of productivity has not had the converse effect.

${ }^{45}$ This is a critique that can be levied against some variants of the Alternative New Keynesian models. Some of the Greenwald-Stiglitz models, for instance, focus on the role that financial market frictions in the presence of perfect wage and price flexibility generate employment fluctuations.

${ }^{46}$ It may, for instance, be related to the deep structural transformations described earlier in this paper. In that case, it is a large change in technology that is the driver of the downturn, not an underlying problem in the financial sector.
} 
(including the interlinkages among financial institutions). The financial sector cannot be adequately summarized in a money demand equation, as the first two strands of macro-economic analysis attempted to do.

\section{E. Contrasting Policy Implications}

The alternative theories described in the previous subsections differ not only in their interpretation of downturns, but also in the advice they give concerning appropriate policy responses. In this section, we look at three examples.

\section{Monetary policy}

Traditionally, monetary policy has been the instrument of choice in responding to economic fluctuations. But it is clear, in deep downturns, that it may be ineffective, or at least, insufficient. Keynes explained this in term of the liquidity trap, the inability to lower interest rates enough to stimulate investment (or consumption) enough to restore the economy to full employment. This theme has been picked up in some of the recent literature under the concept of the zero lower boundnominal interest rates could not be lowered below zero. (Keynes also explained the ineffectiveness of monetary policy in such a situation by using an analogy: it was like pushing on a string.)

We have already suggested why matters today are different than they were in the Great Depression, when real interest rates were $10 \%$. Obviously, if we lowered real interest rates enough, we could presumably restore the economy to full employment-an interest rate of minus $100 \%$ would change matters. (This is equivalent to just giving money away; later in this lecture, I discuss "money rain.") But that is not what those who are focusing on the ZLB mean. They argue that if only we could lower real interest rates, say to $-4 \%$ (from the minus 2 percent that it was in the aftermath of the onset of the Great Recession) we would have recovered. I have never seen any convincing evidence in support of that contention, and as I noted earlier, if the reason for the continued poor performance of the economy were the zero lower bound (ZLB - the fact that nominal interest rates could not be lowered below zero), intertemporal prices could be changed through tax policies.

The central flaws in the analysis of real business cycles and the New Keynesian models with wage and price rigidities are that (a) they see monetary policy working through interest rates; (b) in these models, there is only one relevant interest rate, the T-bill rate; (c) the institutional arrangements through which credit is made available (banks) makes no difference; and (d) distributional effects are assumed away.

We argued before, though, that there can be credit rationing; and liquidity constraints are especially relevant in deep downturns. If there is credit rationing, then monetary policy affects aggregate behavior through credit availability; and credit availability is affected not just by conventional monetary instruments (open market operations), but also by the whole gamut of micro-and macro-prudential regulations (such as capital requirements).

But even if there is no credit rationing, what matters for firm behavior is the lending rate, not the T-bill rate (few firms can borrow at the T-bill rate-evidence itself of the importance of bankruptcy and 
insolvency). But the spread between the two is endogenous; one of the main objectives of Greenwald and Stiglitz (2003) was to explain that spread. ${ }^{47}$

The literature in the third strand of New Keynesian economics described above explains the ineffectiveness of monetary policy in a way quite different from that focusing on the zero lower bound: Banks are unable or unwilling to lend, both because of shocks to their net worth (as a result of higher than expected defaults) and increases in risk perceptions. In such situations, lowering the T-bill rate (or even a capital injection through preferred shares) has little effect: it may neither lead to a substantial increase in credit availability nor lower interest rates. Banks may, moreover, not pass on lower interest rates to customers (and this may be especially so if markets are not highly competitive).

Moreover, monetary policy can have large distributive effects, and these can undermine its effectiveness. Quantitative easing may have led to a stock market bubble, which may have led to (a slightly) increased consumption by the very rich, though given that it was announced that the intervention was only temporary, it was hard to understand why there would be significant consumption impacts in the absence of significant impacts on intertemporal prices - and these effects were minimal. But the lowering of the income of retired people dependent on the return to government bonds would have been expected to have a significant adverse effect on the consumption of these individuals.

There may be even more adverse effects on the medium term: the lower cost of capital may induce firms to use more capital intensive technology, leading to a jobless recovery, exerting downward pressure on wages. ${ }^{48}$

Fiscal policy ${ }^{49}$

Real business cycle theory argued that fiscal policy was not only unnecessary but ineffective: with the economy always at full employment, more government spending simply displaced private spending. Tax cuts financed by debt simply led individuals to save more.

By contrast, in the more general New Keynesian theories, fiscal policy can be very effective; multipliers can be large-and indeed, they can be even larger with rational expectations (or more generally, with future-oriented individuals). Public investment can, in fact, lead to crowding in of investment, if there is complementarity between public and private investment. ${ }^{50}$ There can be crowding in of consumption, if there are expectations of future higher incomes. (Neary and Stiglitz, 1983.)

A large balanced budget multiplier means that expansionary fiscal policy can work even with budget constraints.

\footnotetext{
${ }^{47}$ They explain why the bank lending rate is not just the risk-adjusted T-bill rate.

${ }^{48}$ For a more extensive discussion of these distributive issues, see Stiglitz (2015b).

${ }^{49}$ For an excellent parallel discussion of how the alternative models led to flawed policy conclusions, see Mason and Jayadev (2013).

${ }^{50}$ As seemed to be the case during the Great Depression. See Alex Field $(2003,2011)$.
} 
Still, in the NK models with price rigidities, there was a strong preference for the use of monetary policy, except in the limiting case of the ZLB, and it is important to know why. It is largely is because the fashionable versions of these models are designed to exhibit Ricardian equivalence.

\section{Ricardian equivalence}

For instance, a tax cut financed by government borrowing induces individuals to save more, to repay the liability which they will have to pay in the future. Consumption is unchanged. The conditions under which Ricardian equivalence holds are, of course, very restrictive, but the NK models with price rigidities typically embrace all of the special conditions required. While Stiglitz (1988) showed that Ricardian equivalence holds under much more general conditions than those assumed by Barro-and for a much wider range of public financial operations-it did not hold when there was credit rationing or other forms of financial restraints. Nor did it hold in general in models with finite lived individuals.

But even within the infinite life-time dynastic models with perfect markets, Ricardian equivalence doesn't hold, as we noted above, if public spending goes for public consumption that are not perfect substitutes for private investment goods or for public investment goods that are not a perfect substitute for private investment goods, and this is true whether there is market clearing or not.

There is a second reason that the rigid price NK models with full employment focus on monetary policy-seen as changing intertemporal choices. Consider the limiting case where there is no labor supply elasticity. Then in such models, incomes are fixed. That means that if we are to achieve full employment today, we simply have to shift enough of lifetime demand into the current period; with some intertemporal substitution we can always do that. If we can just adjust real intertemporal prices correctly, we can easily achieve full employment every period. The price rigidities mean that welfare may not be as high as it would be in the first best world of RBC; but at least, we have "solved" the macro-economic problem. (With variable employment, matters are slightly more complicated, because there can be income effects from the changes in intertemporal prices, as individuals decide to supply more or less labor.)

\section{Reduced payroll taxes}

The consequences of a temporary reduction in the payroll tax illustrate the sensitivity of results to particular assumptions. Assume that there is a temporary shift in demand away from the present, that leaves aggregate demand today weak. In models with wage flexibility (even NK models with rigid prices) wages will fall until markets clear, and employment decreases. In models with rigid (real) wages, there will be unemployment. Assume the government wishes to smooth out the fluctuation by reducing the payroll tax. Standard theory says it doesn't make any difference to the competitive equilibrium on whom the tax is levied, whether the worker or the firm; but in the discussion below, we focus on how in the short run, adjustments differ and that matters for the short run equilibrium. Consider an institutional arrangement where the payroll tax is paid by workers, and the reduced tax increases the paycheck received by the worker. With Ricardian equivalence, the worker saves the entire amount. In reality, he doesn't-partly because he may be financially constrained, partly because he assumes the debts will be paid by someone else's great grandchildren. If workers spend more, aggregate demand 
increases and unemployment falls. In NK models with full employment, it is the supply side effect that dominates: at the higher real wage, workers want to work more. There is a shift in the demand and supply curve for labor. If the payroll tax cut is temporary, little of the extra income will be spent this period, so the demand effect is limited, and the supply effect may be larger-this period of high after tax wages is a good time to work. To accommodate the greater labor supply, the wage paid by the firm must fall. There is thus some redistribution effect; but in representative agent models, where the worker also owns the firm, these redistributive effects can be ignored.

There is a problem: if there is a large labor supply elasticity and little extra demand, there will be an excess supply of labor. Normally, monetary policy can accommodate this, shifting demand forward. But with the ZLB, this is not possible. Hence, the main effect of the payroll tax cut is to lower before tax wages, leaving after tax wages little changed. The payroll tax cut is not very effective.

This assumes, of course, that prices don't adjust. But if there is some price flexibility, the lower wage that results induces a slightly lower price (those firms that can lower prices do so), and this induces even more first period consumption. (In principle, we need to consider further reactions on labor supply and consumption in later periods, and how these reverberate back to the first. We assume these second round assumptions are of second order importance.)

The alternative strand of NK models argues that this analysis underestimates the effects on employment by (a) underestimating the current effect on aggregate demand by assuming Ricardian equivalence and ignoring the role of finance constraints for most individuals; and (b) overestimates the labor supply side effect $-{ }^{51}$ Output increases, not because workers are willing to work more, but simply because there is more demand. These effects are especially marked in a world with wage and price rigidities, so that in the initial situation, there is unemployment. The labor supply effect is then largely irrelevant.

In the case where there is some price flexibility, the alternative strand of NK models would suggest too that the intertemporal substitution effect-shifting consumption forward in time-is overestimated. At the same time, so are the implications of the ZLB.

In the Fisher/Greenwald/Stiglitz models with price flexibility, there is, however, a slightly offsetting effect: a transfer of wealth as a result of the lower prices from debtors to creditors, and this diminishes the magnitude of the multiplier. ${ }^{52}$

But now assume that the tax is imposed on the employer, and thus he sees the cost of labor as lowered. If prices remain unchanged, as in the NK fixed price models, his profits increase, and the owners of the firm are wealthier; but they see that as being offset by the same amount as their future tax liability.

\footnotetext{
${ }^{51}$ This is especially so in the presence of real wage rigidities: in periods of high unemployment workers typically do not join the labor market, even if wages are slightly higher (though there is some literature suggesting that unemployment can, under some circumstances, elicit an even greater increase in labor supply as more family members struggle to find a job. See Basu et $a / 2002$ and the references cited there. If there were a labor supply side effect, it could have a significant adverse effect on aggregate demand because of the adverse distributive effect.

${ }^{52}$ Note, however, that if the creditors are constrained in their lending, e.g. by capital requirements, they can expect lending, and this effect could predominate.
} 
Labor is cheaper, so they increase their demand for labor, and this drives up the wage. There are redistributive consequences, but in a representative agent model, these do not matter. But again, with the after tax wage lower, if there is some flexibility in prices, prices today will fall, and this will shift consumption forward in time, with all the consequences that we previously described.

Again, compared to the other NK models, the demand effects may be underestimated, because of the assumption of Ricardian equivalence, or overestimated, because of the absence of redistribution effects. So too, the analysis underestimates the benefits from the strengthening of firms' balance sheets, while the intertemporal substitution effects are overestimated.

The point of this lengthy exercise is to emphasize that the results of any policy change can depend critically on the assumptions, about what constraints are binding, about labor supply elasticities and intertemporal substitutability, and about the magnitude of redistributive effects. ${ }^{53}$

The achievement of modern macro-economics in recent years is to construct models within which a wide range of policies can be debated. The question then becomes, what are the most plausible models? Which ones best capture what is going on? In constructing good models of deep downturns, what matters is not so much how well the model "works" in good times, but how well it explains the details of what we observe in these rare but highly important situations.

\section{Open Economies}

The analysis of small open economies offers many advantages: prices can be taken as given, countries can borrow and lend, etc. But there are some difficulties: a small adjustment of exchange rates would normally confront the economy with unlimited demands. How, then, can aggregate demand be a problem?

Greenwald and I in our joint work took one approach: we focus just on domestic supply. With imperfections in financial markets, the amount that firms are willing to produce, the amounts that they are willing to spend on investment, and the amount of labor they are willing to hire will be limited. We focused on how these variables were interrelated and would be affected by various shocks and policies.

Guzman and I in our joint work have taken another approach: there is a large non-tradeable sector, and resources cannot move perfectly between the tradeable and non-tradeable sector. Their models help us understand better the failure of programs of austerity in Greece and many of the other countries in

\footnotetext{
${ }^{53}$ Thus Eggertsson (2011) presents an elegant NK DSGE model with fixed prices in which he shows that labor tax cuts are contractionary in the presence of the ZLB. But while he calls it a "micro-founded" model, it is a very special model, in which Ricardian equivalence holds, there are no financial constraints, and individuals live infinitely long. While he uses the Dixit-Stiglitz model, a key feature of that model is monopolistic competition with constant elasticity demand curves, an implication of which is that prices (net of taxes) are a fixed mark-up over costs (gross of taxes). And yet, as he says, in the model "An important assumption is the price the firm sets is exclusive of the sales tax." (p. 66-67). Moreover, while there may be a normal process of price adjustment (in a Calvo type model), it seems arbitrary to assume that the pattern of price adjustments either for a once and for all or a one-time tax change would be the same as that for those induced by other changes in factor costs or demand.
} 
the euro-crisis. It was hoped that austerity would lead to wage and price decreases; lower costs, it was thought, were necessary to increase competitiveness, in the presence of exchange rate rigidities.

But there are adverse effects on non-traded goods' demand, especially since some of the distributive benefits of lower wages are garnered by the foreign owners of the firms within the country ${ }^{54}$; and their gains do not lead to increases in the demand for non-traded goods. These adverse effects on the nontraded goods sector can more than offset any benefits from international competitiveness. Even worse, the increased bankruptcy among producers of non-traded goods has spillover effects on producers of traded goods (e.g. through the banking system), and these effects can be so large that there may be no increase in exports. This happened during the East Asia crisis, and, more recently, in Greece.

\section{Debt policy}

The third area of policy is one which has been given short shrift by economists, but seems especially relevant in the current context, where many economies seem plagued with excess leverage. The process of deleveraging and restoring balance sheets is slow. Debt restructuring may be an effective way of restoring aggregate demand more quickly.

Standard economic models would have suggested that such debt restructuring would have little effect: some individuals wealth has increased (those whose debts have been written down), but others have decreased. It is simply a matter of redistribution.

But as we argued earlier, such redistributions do matter. The increase in spending by those whose debt has been reduced (who now face a less binding financial constraint) more than offsets any reduced spending by the creditors. In fact, because of what we referred to earlier as pseudo-wealth, the latter effect may be particularly small: the creditors had, in any case, dim expectations of being repaid. There is a positive increase in the value of aggregate "perceived" wealth.

Inflation used to be an effective way of debt restructuring-in real terms the debts of the debtors got written down. But this approach no longer seems acceptable.

In Stiglitz (2010a) I argued that government should have enacted a homeowners' chapter 11 that would have allowed underwater homeowners to do a debt for equity swap. There was enormous deadweight loss from the foreclosure process (and more inequities than even the critics had anticipated, as a result of the robo-signing scandal, where the banks falsely signed thousands of affidavits concerning the debt obligations of homeowners). There was enormous resistance from banks, who were worried about the consequences of the debt write-offs, even if they were simply recognizing losses that had already occurred-accounting "reforms" had allowed the banks to postpone the recognition of these losses.

\footnotetext{
${ }^{54}$ To avoid these important distributive effects, most of the NK representative agent literature assumes that foreigners lend but do not invest, an assumption which is increasingly unrealistic in our globalized economy.
} 
The Obama Administration refused to support this reform which would have helped rejuvenate the economy-part of their almost single minded focus on supporting the banks ${ }^{55}$.

\section{Contestable democracies}

Economists have traditionally divided policy analyses into temporary and permanent changes. But in the real world, there may be a disparity between what the government announces and what agents in the economy believe, and for good reason: in a democracy, each government has only a limited ability to commit future governments, and market participants know this. Sometimes, governments actively participate in the charade: the Bush Administration announced a temporary cut in the estate tax (down to zero in one year). It did this because of budget rules, according to which the country couldn't afford a permanent cut. But the Bush Administration clearly believed that the political economy was such that once the tax rate reached zero, it would be difficult to raise it again.

In the previous sections, we have considered various measures designed to help the economy get out of a deep downturn. Typically, the measures are announced as temporary. But the effects of the measures depend on beliefs about future policy. Korinek and Stiglitz (2008) have explored how those beliefs affect behavior of market participants, how the knowledge of those behavioral effects the behavior of political actors, and the stochastic equilibrium which thus arises in contested democracies.

\footnotetext{
${ }^{55}$ Reinforced by a concern that if the banks were forced to recognize the losses, they might need more money for recapitalization.
} 


\section{The capitalist economy as a credit economy}

The previous part of this lecture has argued that an understanding of the financial market needs to be at the center of any analysis of deep downturns. Earlier work emphasized the importance of information asymmetries and the role that particular institutions, such as banks, play in dealing with these problems. The failure of much of the standard macro-economic literature to deal with finance and these deep seated information problems accounts for much of the failure of modern macro-economics, and the failure of policy makers to adopt regulatory frameworks that might have prevented the latest deep downturn. For instance, they "bought" into the "completing the markets agenda," suggesting that structured financed and securitization was leading to a more efficient market-without enquiring whether it in fact was leading to a more efficient distribution of risk and without asking whether there was an attenuation in informational incentives. They seemingly did not understand how new moral hazard problems were being created-for instance, incentives to create defective mortgages were increased, and the market responded to these incentives. Nor did they understand how by opening up new betting opportunities, these "market innovations" were actually increasing market volatility. (Guzman and Stiglitz, 2014, 2015a, 2015b.)

In this part of the lecture, I want to revisit one aspect of the financial sector which has proved particularly problematic: the provision of credit. It was evident after the crisis that private markets did not do a particularly good job in the allocation of credit; and similar criticisms could be raised in earlier crises.

\section{The central role of credit}

Traditional monetary economics has focused on money, but in our earlier work, Greenwald and I emphasized what was really important in determining aggregate behavior is credit. Typically, changes in money and credit are highly correlated, which is why econometric analyses typically show a high correlation between money and the level of economic activity. But especially in crises, central banks can expand base money, but the supply of credit may not respond in ways that they normally do, with the result that economic activity does not expand. Keynes was right in emphasizing the inefficacy of monetary policy in such circumstances; but he was wrong in attributing that to a liquidity trap, at least as he conceived of it, due to a horizontal demand curve for money. Rather, we argue that it is related to the unwillingness of banks in such circumstances to increase the supply of credit, even though the constraints that normally limit their supply have been reduced.

Beyond the corn economy: credit creation in a modern economy

In our earlier work, we argued that the traditional argument that the role of banking as intermediating between savers and investors was simply wrong, at least for a modern economy. ${ }^{56}$ The simple models of financial markets as intermediators provide a description of a corn economy, where some farmers have more seed than they want to plant or consume, and others want to consume/plant more seed than they have. In this simple economy, those with excess seed bring that seed to the banks, which intermediate between the savers and the investors. In this world, a good system of intermediation is simply one with

${ }^{56}$ This part of the lecture draws heavily upon Greenwald and Stiglitz (2003). 
low transactions costs. Markets clear the demand and supply of seed: the interest rate serves to equilibrate the two. ${ }^{57}$

But this model provides a poor description of our economy today. What enables individuals to spend more than the resources they have available (either for consumption or investment) is access to credit. Credit is different from ordinary commodities. In particular, credit can be created out of thin air. If the bank gives me a piece of paper which others accept, I can buy goods with it, increasing aggregate demand. The bank can create these pieces of paper almost at will. (There are limits, which I shall discuss in a second.) But this is markedly different from the seed economy discussed earlier: the bank then could only lend out seeds if someone else had deposited the seeds-in effect, had lent the seeds to the bank.

\section{Macro-economic consequences of changes in credit availability}

With aggregate demand depending on credit availability, changes in credit availability can have macroeconomic consequences. For reasons that we have already explained, adjustments in prices do not instantaneously offset these increases in credit. Moreover, there is no presumption that the market supply of credit will ensure aggregate demand equaling aggregate supply. A key function of monetary policy is to provide the requisite coordination: to ensure that the aggregate demand for goods equals the aggregate supply. In the seed economy, there was no need for this-the interest rate adjusted to make sure that the demand for seed equaled the supply.

\section{Trust as the basis of credit}

This poses the central question: what limits the banks' provision of credit; and what would limit it in the absence of constraints imposed by monetary authorities?

A credit economy is based on trust, and in particular, trust that the money that is borrowed will be repaid; and trust that the money that is received will be honored by others. If a financial institution is trusted, it can create "money" ("credit") on its own, issuing IOU's that will be honored by others. (It can thereby increase effective demand; but if the bank is relatively small, it will not take into account these macro-economic externalities of its actions.)

In the "old model" of a credit economy, there was a strong system of accountability for banks issuing IOU's. There was unlimited liability. If the bank issued loans that are not repaid, the owners of the bank would suffer the consequences.

But the old model often didn't work. The ability to punish banks and bankers for bad lending was limited. And these problems became worse with the evolution of limited liability, which was necessary and inevitable as the economy became more complex and the banks became larger. It was virtually impossible in a very large partnership for each partner to monitor the others; with unlimited liability partnerships, each partner was fully accountable for the mistakes of all the others. (Greenwald and

\footnotetext{
${ }^{57}$ This is formalizes Dennis Robertson's theory of loanable funds as the basis of the determination of the interest
} rate. 
Stiglitz, 1992.) With limited liability it was difficult-essentially impossible-to hold those in corporations accountable. But the very size of the banks themselves made it also nearly impossible for depositors to effectively monitor the bank. And these problems were exacerbated by increasing complexity of financial system - to the point where not even financial regulators seem capable of assessing the financial position of financial institutions-with multiple instances of a bank's collapse just shortly after its supervisors had given it a clean bill of health. In short, no one can really monitor the large banks.

The result, even before the financial sector reached anything near the complexity of that of today, was episodic financial panics, as people rush to withdraw funds from financial institutions that had lost their trust. The sudden disappearance of confidence could lead to macroeconomic fluctuations.

In a modern economy, the government stands behind "trust" in the financial system

Today, underlying "trust" in the financial system is the belief that government will come to the rescue, that it is able and willing to do so, and that government is adequately regulating the financial system. Thus, the creation of deposit insurance helped prevent runs, and the strong regulatory system provided confidence in the system as a whole.

After the new regulatory system was created in the aftermath of the Great Depression, we went for decades without a financial crisis. But then two things happened: first, the financial system got better in evading the regulations; and secondly, they exercised their political influence to strip away many of the regulations which had worked so well-arguing in part that because we hadn't had a crisis, they were no longer needed (when in fact, we had not had a crisis precisely because we had had these regulations). Moreover, they used their political influence to put in place regulators, like Alan Greenspan, the long serving chairman of the Federal Reserve, that didn't understand the rationale behind regulation, and didn't believe that regulation was necessary.

\section{Bankers' moral hazard}

The (realistic) belief that government will come to the rescue exacerbates the moral hazard problembanks know that if they make high interest high risk loans, if things work out well, they walk away with the profits; if things turn out badly, the government picks up the losses. (I have described this as a system of ersatz capitalism - privatizing gains and socializing losses. (Stiglitz (2010a).) I should emphasize that the problem that I am emphasizing is the distortion of banks' incentives. Some have talked about how deposit insurance attenuates depositor incentives to monitor banks-and have even argued on these grounds that there should be no deposit insurance. I believe this is wrong: no depositor could possibly monitor an institution as complex as Citibank. If the individual attempted to do so, he would have no time to make any money to deposit into the bank. As we noted earlier, not even full time regulators have done a very good job. 
More fundamentally, monitoring is a public good-all depositors benefit from ensuring that the bank behaves well; and hence bank regulation and supervision should be publicly provided. ${ }^{58}$

The moral hazard problem is, of course, worse for financial institutions that are too big, too interconnected, and too correlated to fail. But note that the financial system has incentives to create such institutions. If a bank is too big to fail, it can obtain capital at a lower interest rate (since depositors know that it will be bailed out); and this enables it to expand, unless the government takes countervailing measures, such as charging higher deposit insurance premiums. So too, banks have an incentive to become interconnected, sufficiently enough so that the government cannot allow them to fail.

There are further problems with the too-big-to fail banks: they are too big to be managed, and too big to be held accountable. Thus, even when they were found to have violated the law, enforcement actions were muted, simply because there was a worry about the macro-economic effects of stronger actions. Perhaps most importantly, these big institutions can have disproportionate political influenceshaping regulations, the choice of regulators, bail-outs, and even enforcement actions. Even when the banks were too big to fail, one could have let the bankers, shareholders, and bondholders go. But the big banks were able to use their influence to ensure that this did not happen.

All of this distorts the financial markets: in the absence of tight regulation and offsetting government measures, it leads to excessive risk taking, bad lending, and excessive volatility. Banks expand not on the basis of their efficiency, but simply because of the advantage of size. They undertake contracts (like derivatives) not because they represent efficient risk sharing, but because they help create a system where the bank is too interconnected to fail.

\section{Distortions in the flow of funds}

Of course, the belief that a bank will be rescued is tempered by the government's ability to rescue, giving an advantage to banks from rich countries. The importance of this is suggested by the strong correlation between the CDSs of sovereigns and of the banks within the given country. This helps explain why after the 2008 crisis broke out, money went to the US. It was not because American banks had demonstrated a better ability to manage risk-quite the contrary, they had demonstrated their incompetence. But the US government had already committed itself to a $\$ 700$ billion rescue, and it was clear that more money would be forthcoming if needed. America had both the resources and the "political economy" (with the financial sector exerting enormous influence, especially on the Central Bank, but also on the Treasury) to ensure a bail-out. Confidence in a rescue was not surprisingly far greater than in the weaker economies of the emerging markets, or even most of those in Europe.

\section{Macro-economic volatility and changes in credit availability}

Here, our focus is on credit and macro-economic volatility. Sudden changes in credit availability can result from sudden changes in trust, sudden changes in banks' perceptions of risk, or sudden changes in

\footnotetext{
${ }^{58}$ More precisely, because all depositors in the bank benefit, the costs of this monitoring should be borne by these depositors.
} 
banks' balance sheets (actual and perceived). ${ }^{59}$ These changes in banks' balance sheets, in turn, can occur as a result of changes in market prices, in defaults (actual or anticipated), or what Guzman and I refer to as pseudo-wealth: There can be changes in expected future profits as a result of changes in beliefs or changes in opportunities to make profits from others (e.g. in derivative markets) because of differences in beliefs. All of these affect banks' willingness to lend. In addition, accounting rules combined with banking regulations affect banks' ability to lend. At various times and for various banks, one constraint or the other may be binding.

The 2008 crisis provided an example of a sudden change in willingness to lend-a liquidity crisis. Banks came to distrust other banks; they knew that they didn't even know the state of their own balance sheet, so how could they know that of other banks, so the interbank lending market dried up. The crisis also showed the impact of regulatory constraints and accounting rules. The government shifted from mark to market to what I called "marking to hope" - they were allowed to postpone writing down the value of mortgages so long as there was some hope that they might be repaid.

\section{The Fundamental Macro-economic asymmetry}

A sudden change in access to credit can give rise to macro-economic fluctuations because of a fundamental asymmetry: The loss of wealth or purchasing power (access to credit) may force those who want to spend more than their income to decrease spending in tandem, while those who gain in wealth (and have access to credit) do not have to increase spending in a corresponding way.

There is a similar situation in the international context which is familiar to all of us; but interestingly the analogy and its implications have not been noted. There has been much worry in recent years about global imbalances. Of course, the sum of the deficits in the world must equal the sum of the surpluses. In standard economic theory, where distribution does not matter and there are no financial constraints, these surpluses and deficits would not matter. So what if some country is lending to another?

The problem (which has been long noted, dating at least back to Keynes) is that there is an adverse effect on global aggregate demand from surpluses. The deficit countries are forced to contract spending, while the surplus countries do not have to expand theirs. A good, well-functioning financial system (working in a world with perfect markets) would easily recycle the surpluses, lending it to others, so that there would be global full employment. But global financial markets often fail to work this way. The surpluses in the surplus countries accumulate in reserves, decreasing global aggregate demand. It used to be that some deficit countries would engage in unbridled spending, and this would offset the deficiency in aggregate demand arising from the surplus countries. But over the past quarter century, deficit countries have become more disciplined; even those that could borrow have curbed their spending. And thus the world has emerged into a situation where there is a deficiency in global aggregate demand. (Greenwald and Stiglitz, 2010a, 2010b.)

Particularly problematic are sudden changes: an increase in the price of oil increases the surpluses of the oil exporters and strengthens the balance sheet of oil exporting firms. It also increases the deficits

\footnotetext{
${ }^{59}$ They can (and have) also arise from sudden changes in policy.
} 
of the oil importers and weakens the balance sheet of oil importing firms; but the former do not increase their spending as much as the latter are forced to (or choose to) contract theirs.

Inequality gives rise to corresponding imbalances. Those at the bottom are borrowing (running a deficit), while those at the top are lending (running a surplus.) Those at the bottom who see their incomes decline are forced to reduce spending more than those at the top expand theirs; that is, that would be the case unless something else happens, e.g. the country creates a housing bubble. This allows those at the bottom to continue to spend beyond their income-indeed, as we noted earlier in this lecture, the bottom $80 \%$ of Americans were spending roughly $110 \%$ of their income. This was not, of course, sustainable, and especially so if their spending was based on being able to borrow against their home, the value of which had been inflated by a bubble.

The failure of monetary policy, once again

We suggested earlier, moreover, that the natural adjustment processes may be, at least in the short run, disequilibrating. If the contraction of aggregate demand leads to unemployment and that leads to lower wages (as what, in fact, happened), then aggregate demand is decreased even as the economy attempts to equilibrate.

Easing of monetary policy may not help, or at least help much. Earlier, we explained that what affects borrowers' behavior is not the T-bill rate (the rate at which the government can borrow), but the rate at which they can borrow, and the spread is an endogenous variable. Moreover, many borrowers face credit constraints, and credit availability is also an endogenous variable. Easing of monetary policy may not help simply because it may not lead to much of an increase in credit or much improvement in the terms at which credit is made available.

Indeed the effect of lowering interest rates T-bill rates may itself be ambiguous. Target savers (those who are saving for purchasing a home, financing a college education, or for retirement) will actually increase their saving and retirees depending on income from government T-bills will reduce their consumption. ${ }^{60}$ There are, of course, some offsetting effects. Lower interest rates will lead to an increase in the value of shares, and this could be expected to lead to an increase in spending of the wealthy. The question is, how interest-sensitive is consumption of the very wealthy? How much will they increase their spending, especially if interest rate reductions are expected to be temporary? If a new policy regime (e.g. quantitative easing) introduces new macroeconomic uncertainties, it is even possible that the consumption of the wealthy is reduced. As it has turned out, in spite of record low interest rates, the aggregate savings rate has increased, though perhaps not as much as might have been expected or as much as it would have in the absence of the low interest rates. One of the reasons that savings may be lower than one might have expected is that it takes time for individuals to adjust downward their living standards. Some of those in the bottom $80 \%$ seem willing to spend beyond their means, so long as banks or other financial institutions are willing to lend to them. If the top $20 \%$, with $40 \%$ of US income, save approximately $15 \%$ of their income, then that by itself leads to a national savings rate of $6 \%$. If eventually the bottom $80 \%$ adjusts to living within their means, with a zero savings

\footnotetext{
${ }^{60}$ These effects are not picked up at all in the standard DSGE models.
} 
rate (i.e. not even paying back accumulated debts), then we can expect the savings rate to increase towards $6 \%$, suggesting that the US recovery will remain weak.

Notice here that what is leading to the weak economy and the limited effect of monetary policy is not the zero lower bound: it is that lowering T-bill interest rates simply doesn't provide much of a simulative effect to the economy. Banks may not be willing to lend or lend at more favorable terms; and lower interest rates may have ambiguous effects on aggregate consumption.

\section{Alternative approaches to stimulating the economy}

If lowering interest rates or lowering wages won't lead to full employment and the restoration of aggregate demand, what will? For some governments, there is an easy solution: They can create money and credit. Government has the power to print money-and the power to tax, to make good on their promises. It is these powers which lead to trust in the government and in the government's ability to bailout banks.

In effect, governments have delegated the trust that arises from these powers to the banks, allowing them to profit from the delegated authority. The argument for that is that private banks can do a better job than public institutions, and that there are inevitable "political economy" problems in the public allocation of funds. At best, that would be true if one could align private incentives with public interests, and private returns with social returns. But a central result of the Greenwald-Stiglitz (1986) theorem is that whenever there are information asymmetries and incomplete markets-that is, always, and especially in financial markets - there are pecuniary externalities associated with private actions; and these externalities matter, so that markets are not (constrained) Pareto efficient.

But there are three other systematic market failures associated with the financial system: imperfections of competition, the exploitation of imperfectly informed and often financially unsophisticated consumers, and the special problems of "bail-out" risk that we described earlier.

This delegation has evidently not worked well: transactions costs have been high, there have been enormous market abuses (from market manipulation to predatory lending, from insider trading and connected lending to abusive credit card practices and fraud). The result is that resources have not been well allocated, risks have not been managed well-the markets actually created risks-and the financial sector has played an important role in the increase in inequality. (Stiglitz, 2012a.)

These failures highlight too the political economy problems in the "delegated" solution: for the banks (and especially the big banks) have, as we have noted, used their political power to limit regulation, regulations that might have promoted competition and limited the conflicts of interest, the exploitation of the financially unsophisticated, and the risks imposed on the public. And they have used their political power to extract massive bail-outs from the public. It is evident that political economy problems cannot be avoided. The current arrangements have thus often lead to non-transparent subsidies and distortions. 


\section{The standard approach}

The standard approach in monetary economics to stabilize the economy focuses on enhancing the ability and willingness of banks to provide credit, through changes in rules that make the constraints on their lending less binding and through open and hidden subsidies that increase their net worth, and thus their capacity and willingness to lend. ${ }^{61}$ The hope is that they do so, and that the money goes to increase effective demand, rather than purchasing preexisting assets such as land. It is also hoped that they will allocate the funds to uses with the highest social return and that they don't take advantage of the unwary.

This "solution" hasn't worked: Banks often haven't lent (the real source of the "liquidity trap" today), and when they have lent, money hasn't gone to where it would lead to an increase in effective demand. Indeed, given the risk aversion of banks, it is understandable that they lend against collateral (and some of the rules governing banks may even encourage them to do so). But, lending against collateral means that they disproportionately lend for real estate purchases. Some governments in the past (like that of Thailand) restricted such lending because they wanted funds to go into productive uses, and they didn't want to create real estate bubbles. They were criticized for doing this - these regulations, it was alleged, were interfering with the market.

We have already explained why these arguments were naïve: they didn't take into account the multiple market failures that we have noted, the distortions between private and social returns. But leaving it to the market presents a special problem as far as ensuring macro-stability: it is possible that the level of credit necessary to restore the economy to full employment generates excessive increases in asset prices. And indeed, this has often been the case. One was asking too much of a single instrument (the interest rate). Monetary authorities had at their disposal multiple instruments, including those which would limit the extent of real estate speculation. But in the hey-day of "market fundamentalism," before the 2008 crisis, monetary authorities were discouraged from using these additional instruments. We now know that that was wrong-and the world has paid a high price for this ideologically driven policy. (See Stiglitz 2012b, 2014.)

This analysis helps explain ineffectiveness of monetary policy in the current crisis. Of course, if we had done a better job of fixing the credit channel (a better job at recapitalizing community banks and "fixing" the mortgage market) more of the increased liquidity might have found its way into an increased demand for produced goods, and thus monetary policy might have been more effective.

I should emphasize, the ineffectiveness of monetary policy that I have just described has nothing to do with the traditional Keynesian liquidity trap. Our analysis explains what is really going on: the real constraint is credit availability, and this depends on the behavior of banks. In a deep downturn, it is hard to induce them to lend. ${ }^{62}$

\footnotetext{
${ }^{61}$ I should qualify this: most of the standard monetary economics simply assumes the ability of monetary authorities to do this. It does not actually model bank behavior.

${ }^{62}$ Recall our earlier discussion, where we noted that Keynes' analysis was based on the assumption of a horizontal demand curve for money. Nor does it have anything to do with the zero lower bound to the nominal interest rate
} 
The current approach not only has been ineffective, but it is also politically unsavory. It has entailed giving money (at below market rates) to those who caused the economic crisis to recapitalize them in the hope that this translates into more lending, and not just into more wealth for the banks. Doing so seems "unjust," especially since the argument that it was necessary to "save the economy" was never very persuasive, and especially so after it became clear that little of the money got translated into more lending, and some of it went simply to pay huge bonuses to the bankers. ${ }^{63}$

\section{An alternative solution: Public Lending}

There are alternative solutions. One is to induce banks to focus on lending activities. Indeed, this should have been one of major foci of regulatory reform. These reforms centered around preventing the financial sector doing harm to others; more attention should have been paid to ensuring that the financial sector actually performs the social functions which it is supposed to perform. Both incentives and constraints can play a role: Restricting banks' non-productive activities (like speculation) and providing access to the Fed window on the condition that they expand lending, for instance, to Small and Medium Sized enterprises.

Another is for the government to use its own credit capacity to finance high-return public investments and to address other major social needs, such as those related to growing inequality or climate change.

There already is, of course, some direct lending by the government in many countries, even in more privately oriented systems like the US (for instance, student loans). But this should be greatly expanded, for instance to mortgage lending. The US government already underwrites most mortgages. Most conventional mortgages are written based on standard scoring methodologies, and the relevant information is all within the hands of the government (such as past income and real estate transactions). ${ }^{64}$ There are large economies of scope both in the processing of this information and in collection through tax authorities. ${ }^{65}$ The criticism of such lending, as already noted, is that government is not good at lending; but there is an obvious response: neither is the private sector; in fact, arguably no government has ever wasted money at such great cost to society as a whole as the US private financial sector. Government has done a better job at least in some areas and does not seem to have the perverse incentives to behave badly that are pervasive within the private financial sector.

\section{Money rain}

which has received so much attention as of late. As we explained earlier, it is implausible that simply by lowering the real interest rate from minus two percent to say minus four percent, the economy will be restored to full employment. Earlier, we explained why aggregate demand might not be very sensitive to changes in real interest rates. (See Greenwald and Stiglitz, 2003, for a discussion of both the theory and evidence.)

${ }^{63}$ The payment of such bonuses needs, of course, to be modeled. It is a reflection of corporate governance problems that are pervasive in the corporate sector, but appear especially prominent within the financial sector. ${ }^{64}$ The current system relies heavily on warranties and representations by the private sector that the mortgages that they have originated are as they say they are. The crisis revealed massive fraud on the part of the originators and massive breaking of contracts. To enforce contracts, the government has had to pay huge litigation costs. Direct public lending would avoid these problems.

${ }^{65}$ This was one of the main arguments put forward for government income contingent loans. See, e.g. Stiglitz (2015). 
There is a final alternative, proposed long ago by Milton Friedman ${ }^{66}$ : Money rain-simply sprinkling money around the economy. It would induce more spending (except under the unlikely condition that prices are adjusted fully, proportionately, and instantaneously). This would not be inflationary, so long as the amounts were appropriately calibrated. (Money rain can be viewed as the limiting case of lending with a minus $100 \%$ interest rate.) In many countries (e.g. US) the problem is not an insufficiency of consumption, but of investment, and broad based money rain would restore full employment by encouraging consumption. To me, the solution of government using its credit creating capacity to increase the productive capacity of the economy is a far better way of restoring the economy to full employment.

\section{The crisis in economics}

The 2008 crisis was not only a crisis in the economy, but it was also a crisis for economics-or at least that should have been the case. As we have noted, the standard models didn't do very well. The criticism is not just that the models did not anticipate or predict the crisis (even shortly before it occurred); they did not contemplate the possibility of a crisis, or at least a crisis of this sort. Because markets were supposed to be efficient, there weren't supposed to be bubbles. The shocks to the economy were supposed to be exogenous: this one was created by the market itself. Thus, the standard model said the crisis couldn't or wouldn't happen; and the standard model had no insights into what generated it.

Not surprisingly, as we again have noted, the standard models provided inadequate guidance on how to respond. Even after the bubble broke, it was argued that diversification of risk meant that the macroeconomic consequences would be limited. The standard theory also has had little to say about why the downturn has been so prolonged: Years after the onset of the crisis, large parts of the world are operating well below their potential. In some countries and in some dimension, the downturn is as bad or worse than the Great Depression. Moreover, there is a risk of significant hysteresis effects from protracted unemployment, especially of youth.

The Real Business Cycle and New Keynesian Theories got off to a bad start. They originated out of work undertaken in the 1970s attempting to reconcile the two seemingly distant branches of economics, macro-economics, centering on explaining the major market failure of unemployment, and microeconomics, the center piece of which was the Fundamental Theorems of Welfare Economics, demonstrating the efficiency of markets. ${ }^{67}$ Real Business Cycle Theory (and its predecessor, New Classical Economics) took one route: using the assumptions of standard micro-economics to construct an analysis of the aggregative behavior of the economy. In doing so, they left Hamlet out of the play: almost by assumption unemployment and other market failures didn't exist. The timing of their work couldn't have been worse: for it was just around the same time that economists developed alternative micro-theories, based on asymmetric information, game theory, and behavioral economics, which provided better explanations of a wide range of micro-behavior than did the traditional theory on which the "new macro-economics" was being constructed. At the same time, Sonnenschein (1972) and

\footnotetext{
${ }^{66}$ Friedman (1969).

${ }^{67}$ For a more extensive discussion of this point, see Greenwald and Stiglitz, 1987a.
} 
Mantel (1974) showed that the standard theory provided essentially no structure for macroeconomics-essentially any demand or supply function could have been generated by a set of diverse rational consumers. It was the unrealistic assumption of the representative agent that gave theoretical structure to the macro-economic models that were being developed. (As we noted, New Keynesian DSGE models were but a simple variant of these Real Business Cycles, assuming nominal wage and price rigidities - with explanations, we have suggested, that were hardly persuasive.)

There are alternative models to both Real Business Cycles and the New Keynesian DSGE models that provide better insights into the functioning of the macro-economy, and are more consistent with microbehavior, with new developments of micro-economics, with what has happened in this and other deep downturns. While these new models differ from the older ones in a multitude of ways, at the center of these models is a wide variety of financial market imperfections and a deep analysis of the process of credit creation. These models provide alternative (and I believe better) insights into what kinds of macroeconomic policies would restore the economy to prosperity and maintain macro-stability.

This lecture has attempted to sketch some elements of these alternative approaches. There is a rich research agenda ahead. 


\section{References}

Allen, F. and Douglas M. Gale, 2000, "Financial Contagion," Journal of Political Economy, 108(1): 1-33.

Ariely, D., 2010, Predictably Irrational: The hidden forces that shape our decisions, New York: Harper Perennial.

Basu, K., Garance Genicot and J. E. Stiglitz, 2002, "Minimum Wage Laws and Unemployment Benefits, When Labor Supply is a Household Decision," in Markets and Governments, K. Basu, P. Nayak, and R. B. Ray (eds.), in Oxford University Press, pp.38-59.

Battiston, S., D. Delli Gatti, B. Greenwald and J. E. Stiglitz, 2007, “Credit Chains and Bankruptcy Propagation in Production Networks," Journal of Economic Dynamics and Control, 31(6): 2061-2084.

Battiston, S., Domenico Delli Gatti, Mauro Gallegati, Bruce Greenwald, and J. E. Stiglitz, 2012a, "Default Cascades: When Does Risk Diversification Increase Stability?" Journal of Financial Stability, 8(3): 138-149.

- - , - - - - - - and - - 2012b, "Liaisons Dangereuses: Increasing Connectivity, Risk Sharing, and Systemic Risk," Journal of Economic Dynamics and Control, 36(8): 11211141.

Battiston, S., Guido Caldarelli, Co-Pierre Georg, Robert May, and J. E. Stiglitz, 2013, "Complex Derivatives," Nature Physics, 9(March): 123-125.

Bernanke, B. and Mark Gertler, 1990, "Financial fragility and economic performance," Quarterly Journal of Economics, 105(1): 87-114.

Delli Gatti, D., M. Gallegati, B.C. Greenwald, A. Russo, and J. E. Stiglitz, "Sectoral Imbalances and Long Run Crises," The Global Macro Economy and Finance, F. Allen, M. Aoki, J.-P.

Fitoussi, N. Kiyotaki, R. Gordon, and J.E. Stiglitz, eds., IEA Conference Volume No. 150-III, Houndmills, UK and New York: Palgrave, pp. 61-97.

,,,-------- and - - "Mobility Constraints, Productivity Trends, and Extended Crises," 2012, Journal of Economic Behavior \& Organization, 83(3): 375- 393.

Eaton, J., 1986, "Lending with Costly Enforcement of Repayment and Potential Fraud,"Journal of Banking and Finance, 10(2), pp. 281-93.

Eaton, J. and Mark Gersovitz, 1981, "Debt with Potential Repudiation Theoretical and Empirical Analysis," Review of Economic Studies, 48(2), pp 289-309.

Eggertsson, Gauti, 2011. The NBER Macroeconomics Annual, 2010, vol. 25, ed. Daron Acemoglu and Michael Woodford, NBER.

Eisenberg, L. and Noe, T. H., 2001, "Systemic Risk in Financial Systems," Management Science, 47(2): 236-249. 
Farhi , Emmanuel and Ivan Werning, 2015, A Theory of Macroprudential Policies in the Presence of Nominal Rigidities, paper presented to 2015 meeting of the ASSA, Boston, January.

Field, Alexander J., 2003, "The Most Technologically Progressive Decade of the Century," American Economic Review, 93(4): 1399-1413. , 2011, A Great Leap Forward: 1930s Depression and US Economic Growth, New Haven: Yale University Press.

Fisher, Irving, 1933, "The Debt Deflation Theory of Great Depressions," Econometrica, 1(4): $337-$ 357.

Friedman, Milton, 1969. The Optimum Quantity of Money, London: Macmillan.

Gallegati, M., B. Greenwald, M. Richiardi, and J. E. Stiglitz, 2008, "The Asymmetric Effect of Diffusion Processes: Risk Sharing and Contagion," Global Economy Journal, 8(3): Article 2.

Greenwald, B. and J.E. Stiglitz, 1986, "Externalities in Economies with Imperfect Information and Incomplete Markets," The Quarterly Journal of Economics, 101(2): 229-64.

- - and - - 1987a, "Keynesian, New Keynesian and New Classical Economics," Oxford Economic Papers, 39: 119-133.

- - and - - 1987b, "Imperfect Information, Credit Markets and Unemployment," European Economic Review, 31: 444-456.

- - and - - 1988a, "Money, Imperfect Information and Economic Fluctuations," Finance Constraints, Expectations and Macroeconomics, M. Kohn and S.C. Tsiang (eds.), Oxford: Oxford University Press, pp.141-165.

- - and - - 1988b, "Examining Alternative Macroeconomic Theories," Brookings Papers on Economic Activity, 1: 207-270. Subsequently reprinted in Recent Developments in Macroeconomics, Edmund Phelps (ed.), Edward Elgar, 1991, pp. 335-388.

- - and - - 1988c "Imperfect Information, Finance Constraints and Business Fluctuations," Finance Constraints, Expectations, and Macroeconomics, M. Kohn and S.C. Tsiang (eds.), Oxford: Oxford University Press, pp. 103-140.

- - and - - 1988d "Information, Finance Constraints and Business Fluctuations," Symposium on Monetary Theory (Proceedings of Taipei), Institute of Economics, Academia Sinica, pp. 299-336.

- - and - - 1989, "Toward a Theory of Rigidities," American Economic Review, 79(2): 364-69.

- - and - - 1990a, "Asymmetric Information and the New Theory of the Firm: Financial Constraints and Risk Behavior," American Economic Review, 80(2): 160-65. 
-- and --, 1990b, "Macroeconomic Models with Equity and Credit Rationing," Asymmetric Information, Corporate Finance, and Investment, R. B. Hubbard (ed.), University of Chicago Press, 1990, pp. 15-42.

- - and - - 1991, "Toward a Reformulation of Monetary Theory: Competitive Banking," Economic and Social Review 23(1): 1-34. Also NBER Working Paper 4117. (Paper prepared for the Irish Economic Association Annual Conference, Dublin, May 1991, and Caffee Lectures presented to the University of Rome and the Bank of Italy, Rome, April 1991.)

- - and - - 1992, "Information, Finance and Markets: The Architecture of Allocative Mechanisms," Industrial and Corporate Change, 1(1),: 37-63. Also in Finance and the Enterprise, V. Zamagni (ed.), Academic Press, 1992, pp. 11-36.

- - and - - 1993a, "Financial Market Imperfections and Business Cycles," Quarterly Journal of Economics, 108(1): 77-114.

- - and - -, 1993b “New and Old Keynesians," Journal of Economic Perspectives, 7(1): 23-44.

- - and - - , 1995. "Labor Market Adjustments and the Persistence of Unemployment," American Economic Review, 85(2): 219-225.

- - and - - 2003a, Towards a New Paradigm in Monetary Economics, Cambridge: Cambridge University Press.

- - and --, 2003b, "Macroeconomic fluctuations in an economy of Phelps-Winter markets," in Knowledge, Information, and Expectations in Modern Macroeconomics: In Honor of Edmund S. Phelps, P. Aghion, R. Frydman, J.E. Stiglitz and M. Woodford (eds.), Princeton: Princeton University Press: pp. 123-136.

- - and - - 2010a, "Towards a New Global Reserves System, Journal of Globalization and Development, 1(2), Article 10.

- - and - - 2010b, A Modest Proposal for International Monetary Reform," in Time for a Visible Hand: Lessons from the 2008 World Financial Crisis, S. Griffith-Jones, J.A. Ocampo, and J.E. Stiglitz (eds.), Initiative for Policy Dialogue Series, Oxford: Oxford University Press: pp.314-344.

- - , - , and A. M. Weiss, 1984, "Informational Imperfections in the Capital Market and Macroeconomic Fluctuations," American Economic Review, 74(2): 194-99. I

Guzman, Martin, 2013, Overborrowing Crises and The Role of Expectations. In Guzman, Martin (2013), Understanding the Causes and Effects of Financial Crises, Brown University Doctoral Dissertation, Chapter 1. 
Guzman, Martin and J.E. Stiglitz, 2014, "Pseudo-wealth and Consumption Fluctuations", paper presented to the 17th IEA World Congress, and to be published in the Proceedings, Palgrave-McMillan.

- - and - - 2015a, "Pseudo-Wealth Fluctuations and Aggregate Demand Effects", paper presented to the American Economic Association Meetings, Boston, January.

- - and - - 2015b, "A Theory of Pseudo-Wealth", forthcoming in Contemporary Issues in Macroeconomics: Lessons from The Crisis and Beyond, to be published by Palgrave MacMillan, paper originally presented at an IEA/World Bank Roundtable on Shared Prosperity, Jordan, June 10-11, 2014 and at an INET seminar at Columbia University, December 3, 2014.

Hahn, Frank, 1966, “Equilibrium Dynamics with Heterogeneous Capital Goods," Quarterly Journal of Economics, 80(4): 633-646.

Haldane, Andrew G., 2009, "Rethinking the Financial Network," address to the Financial Students Association, Amsterdam, April, available at http://www.bankofengland.co.uk/publications/speeches/2009/speech386.pdf (accessed September 22, 2010).

Haldane, Andrew G. and Robert M. May, 2011, "Systemic risk in banking ecosystems," Nature, 469: 351-355.

Hellwig, M.F., 1977. "A Model of Borrowing and Lending with Bankruptcy," Econometrica, 45(8), pp. 1879-1906

Jeanne, Olivier and Anton Korinek, 2010, "Excessive Volatility in Capital Flows: A Pigouvian Taxation Approach," American Economic Review, 100(2), pp. 403-407

Kindleberger, Charles, 1978, Manias, Panics, and Crashes: A History of Financial Crises, New York: Basic Books.

Koo, Richard, 2011, "The world in balance sheet recession: causes, cure, and politics," realworld economics review, 58: 19-37.

Korinek, A., 2011, "Systemic Risk-Taking: Amplification Effects, Externalities, and Regulatory Responses," working paper, University of Maryland.

Korinek, Anton and Joseph E. Stiglitz, 2008, "Political Economy in a Contestable Democracy" January 20, available at http://www2.gsb.columbia.edu/faculty/jstiglitz/download/papers/2008_Pol_Econ_Cont estable_Demo.pdf (accessed January 11, 2011).

Kydland, Finn E., and Carlos Zarazaga, 2002, "Argentina's lost decade." Review of Economic Dynamics 5, no. 1: 152-165.

Lorenzoni, Guido, 2006, A Theory of Demand Shocks. American Economic Review, 99(5): 205084. 
—-, 2011. "News and Aggregate Demand Shocks." Annual Review of Economics. 3: 537-557.

Lucas, R.E., 1987, Models of Business Cycles, New York: Blackwell.

--, 2003, "Macroeconomic priorities," American Economic Review, 93 (1): 1-14.

Mason, J. W. and Arjun Jayadev, 2013, "Strange Defeat: How the New Consensus In Macroeconomics Let Austerity Lose all the Intellectual Battles and Still Win the War," Economic and Policy Weekly, August 10.

Maljuf, N.S. and S.C. Myers, 1984, "Corporate Financing and Investment Decisions when Firms Have Information that Investors do not Have," Journal of Financial Economics, 13(2): 187-222.

Mendoza, Enrique G. and Vincenzo Quadrini, 2009, “Financial Globalization, Financial Crises and Contagion," NBER Working Paper No. 15432.

McConnell, Margaret M., and Gabriel Perez-Quiros, 2000, "Output Fluctuations in the United States: What Has Changed since the Early 1980's?" American Economic Review, 90(5): 1464-1476.

Minsky, Hyman P., 1992 "The Financial Instability Hypothesis," The Jerome Levy Economics Institute of Bard College, Working Paper No. 74.

Neary, J. Peter and Joseph E. Stiglitz, 1983, "Toward a Reconstruction of Keynesian Economics: Expectations and Constrained Equilibria," The Quarterly Journal of Economics, 98, Supplement: 199-228.

Popov, Alexander and Gregory F. Udell, 2010, "Cross-Border Banking and the International Transmission of Financial Distress During The Crisis of 2007-2008," European Central Bank Working Paper Series, No. 1203.

Reinhart, Carmen M. and Rogoff, Kenneth, 2009, This Time is Different: Eight Centuries of Financial Folly, Princeton: Princeton University Press.

Roukny, Tarik, Stefano Battiston, and Joseph E. Stiglitz, "The Worst, the Best and the Uncertain," May 31, 2015.

Shapiro, C. and J. E. Stiglitz, 1984, "Equilibrium Unemployment as a Worker Discipline Device," American Economic Review, 74(3): 433-444.

Shell, Karl and Joseph E. Stiglitz, 1967, "The Allocation of Investment in a Dynamic Economy," Quarterly Journal of Economics, 81(4): 592-609. 
Solow, R. and J. E. Stiglitz, 1968, "Output, Employment and Wages in the Short Run," Quarterly Journal of Economics, 82: 537-560.

Stiglitz, Joseph E., "A Re-Examination of the Modigliani-Miller Theorem," American Economic Review, 59(5), December 1969, pp. 784-793.

,-- 1972 . "Some Aspects of the Pure Theory of Corporate Finance Bankruptcies and Takeovers." Bell Journal of Economics and Management Science, 3(2), pp. 458-82.

- - 1974, “Alternative Theories of Wage Determination and Unemployment in L.D.C.'s: The Labor Turnover Model," Quarterly Journal of Economics, 88(2): 194-227.

--, 1982 "Information and Capital Markets," in Financial Economics: Essays in Honor of Paul Cootner, William F. Sharpe and Cathryn Cootner (eds.), Prentice Hall, New Jersey, pp. 118-158.

,-- 1988, "On the Relevance or Irrelevance of Public Financial Policy," in The Economics of Public Debt, Proceedings of the 1986 International Economics Association Meeting, London: Macmillan Press, pp. 4-76.

- - 1992, "Banks versus Markets as Mechanisms for Allocating and Coordinating Investment," The Economics of Cooperation: East Asian Development and the Case for Pro-Market Intervention, J.A. Roumasset and S. Barr (eds.), Westview Press, Boulder, 1992, pp. 1538. (Presented at Investment Coordination in the Pacific Century: Lessons from Theory and Practice Conference, given at the University of Hawaii, January 1990.)

,-- 1994, Whither Socialism? Cambridge, MA: MIT Press.

- - 1999, Toward a General Theory of Wage and Price Rigidities and Economic Fluctuations," American Economic Review, 89(2): 75-80.

- - 2010a. Freefall: America, Free Markets, and the Sinking of the World Economy, New York: WW Norton.

- - 2010b, "Contagion, Liberalization, and the Optimal Structure of Globalization," Journal of Globalization and Development, 1(2), Article 2, 45 pages.

- - 2010c, "Risk and Global Economic Architecture: Why Full Financial Integration May be Undesirable," American Economic Review, 100(2): 388-392.

- - 2011, "Rethinking Macroeconomics: What Failed and How to Repair It," Journal of the European Economic Association, 9(4): 591-645.

- - 2012a, The Price of Inequality, New York: WW Norton

- - 2012b, "Macroeconomics, Monetary Policy, and the Crisis," in In the Wake of the Crisis, O.J. Blanchard, D. Romer, M. Spence, and J.E. Stiglitz (eds.), Cambridge, MA: MIT Press.

- - 2013, "Stable Growth in an Era of Crises: Learning from Economic Theory and History," Ekonomi-tek, 2(1): 1-38. (Originally delivered as keynote lecture to the Turkish Economic Association, Izmir, November, 2012.) 
--, 2014, "The Lessons of the North Atlantic Crisis for Economic Theory and Policy," in What Have We Learned? Macroeconomic Policy after the Crisis, Geroge Akerlof, Olivier Blanchard, David Romer, and Joseph E. Stiglitz (eds.), Cambridge, Mass. and London: MIT Press, pp. 335-347.

- -, 2015a, "Income contingent loans: Some General Theoretical Considerations, with applications," paper presented to the 2014 World Congress of the International Economic Association, to be published in the Proceedings, Palgrave-McMillan.

- - 2015b, "Fed Policy, Inequality, and Equality of Opportunity," paper delivered to the The Ninth Biennial Federal Reserve System Community Development Research Conference, April 3, 2015.

,$-- 2015 c$, "The Measurement of Wealth: Recessions, Sustainability and Inequality" Paper presented at a special session of the International Economic Association World Congress, Dead Sea, Jordan, June, 2014 sponsored by the OECD.

Stiglitz, J. E. and A. Weiss, 1981, "Credit Rationing in Markets with Imperfect Information," American Economic Review, 71(3): 393-411.

- - and - - 1983, "Incentive Effects of Terminations: Applications to the Credit and Labor Markets," American Economic Review, 73(5): 912-27.

- - and - - 1986, "Credit Rationing and Collateral," in Recent Developments in Corporate Finance, J. Edwards et al, eds., New York: Cambridge University Press, pp. 101-135.

Stiglitz, Joseph and Jungyoll Yun, 2005, "The Integration of Unemployment Insurance with Retirement Insurance,", Journal of Public Economics, 89: 2037-2067.

- - and - - 2013, "Optimal Provision of Loans and Insurance against Unemployment from a Lifetime Perspective," NBER Working Paper 19064, May.

- - and - -, 2014, "Income Contingent Loans for the Unemployed: A Preulde to a General Theory of the Efficient Provision of Social Insurance,", in Income Contingent Loans: Theory, Practice and Prospects, Joseph E. Stiglitz, Bruce Chapman, and Timothy Higgins (eds.), Houndmills, UK and New York: Palgrave Macmillan, pp.180-204l.

Townsend, R., 1979. "Optimal Contracts and Competitive Markets with Costly State Verification," Journal of Economic Theory, 21(2): 265-293. 